\title{
22. PLANKTONIC FORAMINIFERAL BIOSTRATIGRAPHY IN THE CENTRAL NORTH PACIFIC OCEAN ${ }^{1}$
}

\author{
Robert G. Douglas, Department of Geology, Case Western Reserve University, Cleveland, Ohio
}

\section{INTRODUCTION}

The eight sites drilled during Leg 17 are located in a triangular area bounded on the north by the Hawaiian Islands, on the south by the equator, on the east by the Line Islands, and on the west by the Marshall-Gilbert Islands (Figure 1). Planktonic and benthonic foraminifera are present in cores from six of the eight sites, which range in age from Quaternary to Cretaceous (Cenomanian/ Albian). Unconformities occur in the Tertiary and Cretaceous at all the drilling sites.

The stratigraphic distribution of Leg 17 cores is shown in Table 1. The best foraminiferal assemblages were recovered at the three shallowest sites $(165,167$, and 171). At these sites foraminifera are generally moderately to wellpreserved, although selective dissolution of species, reworking, and downhole contamination has occurred in many of the cores. Foraminifera are either completely absent or present only in the Cretaceous cores from the five deeper sites $(164,166,168,169$ and 170). The foraminiferal assemblages from all of these sites are sparse and poorly preserved.

The coring strategy adopted during the cruise was to spot core from the sediment-water interface until Oligocene sediments were reached, and then to core as continuously as conditions would permit to the acoustic basement. This strategy yielded discontinuous sections of Neogene at Sites 167 and 171 and nearly complete sections of Oligocene at these two sites and Site 165. Most or all of the Paleocene and lower Eocene is missing at all the drilling sites. Typically, middle Eocene sediments rest directly on late or middle Maastrichtian strata. Cretaceous foraminifera occur at six sites, but the assemblages are, in general, moderately to poorly preserved. The best microfaunas are restricted to Maastrichtian and latest Campanian cores. A thick section of early Cretaceous limestone was cored at Site 167, but examined samples are devoid of foraminifera except for rare fragments of nodosariids.

Planktonic foraminifera were routinely studied as a basis for age dating, zonation, and correlation. For the Cenozoic, the zonal scheme of Blow (1969) was employed. The results from earlier DSDP cruises in the Pacific (Brönnimann and Resig, 1971; Beckmann, 1971; Jankins and Orr, 1972) have shown that Blow's zonation requires modification in the central Pacific because of problems of selective preservation and differences in the stratigraphic ranges of zonal species from those reported by Blow

\footnotetext{
${ }^{1}$ Contribution No. 97, Department of Geology, Case Western Reserve University, Cleveland, Ohio.
}

(1969). Jenkins and Orr (1972) believed that Blow's scheme could not be applied in the eastern Pacific region and proposed a new biostratigraphic zonation, based on planktonic foraminifera. However, their zones closely resemble those of Blow (1969) and Bolli (1957a-c, 1966). The author has applied Blow's zonal definition with certain working modifications: The Quaternary zones N.22 and N.23 were not separated. It is doubtful that N.23 is represented in any of the samples examined during Leg 17 ; they are assigned to the combined zonal interval. In any case, the redefinition of N.23 proposed by Brönnimann and Resig (1971) seems to be more useful than the original faunal definition of the unit. As noted by both Jankins and Orr (1972) and Beckmann (1971), Globigerinoides quadrilobatus primordius is rare or absent in many Pacific samples. The species is especially rare near the base of its range. Recent species of Globigerinoides are among the more easily dissolved planktonic foraminifera (Berger, 1969,1970 ), and it seems likely the early Miocene species were similar and therefore missing for reasons of preservation. Recognition of the base of zone N.4, which defines the base of the Miocene, may rest in large part on the degree of preservation of the sediment. Likewise, Globigerina angulisuturalis and $G$. ciperoensis, key species in definint zones P.21 and P.22 in the late Oligocene, appear to be easily destroyed by epigenetic and diagenetic processes. The base of zone P.21 is defined by the first evolutionary occurrence of $G$. angulisuturalis, evolving from G. anguliofficinalis (Blow, 1969), but this evolutionary transition is impossible to document in any of the Leg 17 cores. Rather, the working definition of the base of P.21 proposed by Beckmann (1971), which uses the first occurrence of Turborotalia opima opima, has been applied. According to Blow (1969), this event is slightly younger stratigraphically than the evolution of $G$. angulisuturalis. Brönnimann and Resig (1971) report that T. opima opima and T. opima nana range throughout zone N.3 (=P.22), but at Site 167 both species disappear near the bottom of zone P.22. Globigerinia ciperonensis first appears at the P.18 to P.19 zonal boundary, but the species does not occur at Site 167 until the upper part of zone P. 19/20. Another irregular stratigraphic range is the extinction of Pseudohastigerina within zone P.18, rather than near the top of zone P.19 (Corday et al., 1970). A similar abbreviated range has been noted in other deep-sea deposits (Blow, 1970).

In general there is good agreement between the species morphology and stratigraphic ranges reported by Brönnimann and Resig (1971), Beckmann (1971), and Jenkins and Orr (1972) and those found in the central North Pacific.

For the late Cretaceous, a slightly modified version of the zonal scheme of Pessagno (1967) was employed. A 


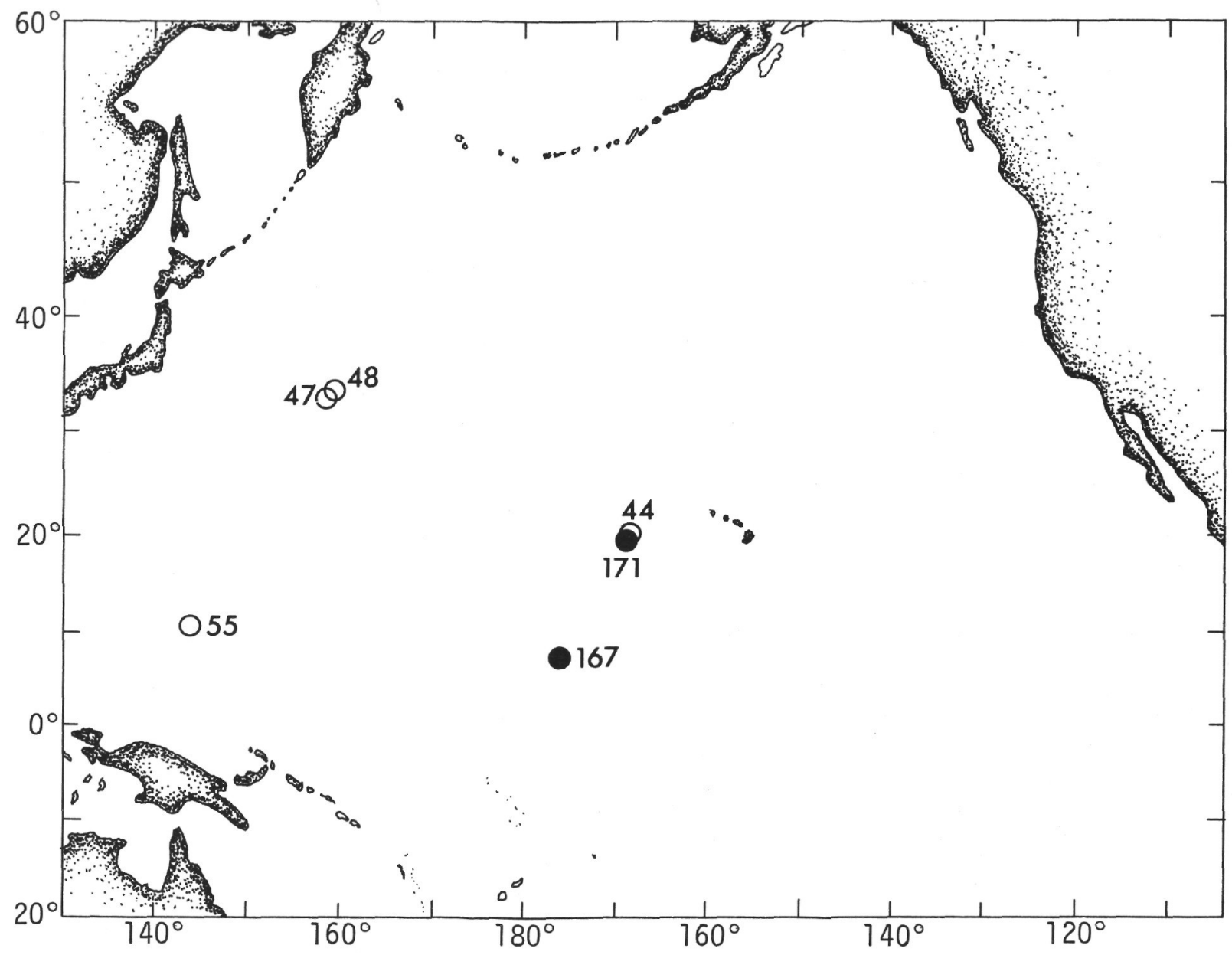

Figure 1. Location map of drilled sites.

zonation based on deep-sea faunas is needed for the Cretaceous, but must await the recovery of more complete sequences of richly fossiliferous sediments. Cretaceous planktonic foraminifera obtained to date from the Pacific are limited to the upper Cretaceous, and no assemblages have yet been recovered from the upper Cenomanian, lowest Turonian, and upper Santonian.

The relative abundance of stratigraphically important species was estimated for Cenozoic samples from Sites 167 and 171. For samples which have suffered considerable dissolution or diagenesis, the meaning of such species frequencies is questionable. Variation in sample size, sample washing techniques, sample induration, etc., affect counts and ratios, and the statistical results are comparable only for samples of comparable preservation and sample size.

\section{PRESERVATION}

Studies of Recent planktonic foraminifera show that dissolution alters species assemblages so that thin-shelled, highly porous shells (e.g., Globigerinoides ruber) are selectively destroyed as compared to thick-shelled, slightly porous shells (e.g., Pulleniateria obliquiloculata) (Berger, 1971b). This process begins as shells settls in the water column and continues after burial. Selective dissolution appears to be the primary agent in the destruction of foraminifera in deep-sea sediments and leads not only to direct removal of shells, but also contributes to breakage and fragmentation of shells (Berger, 1971b). It is evident that dissolution strongly affects information recovery based on planktonic foraminifera.

\section{Magnesium Carbonate Content}

Information on the relative resistance to dissolution of individual species is presently limited to rankings derived from Recent sediments assemblages (Berger, 1970) and indirect observations from fossil assemblages (Douglas, 1971). Another approach to the problem is an examination of the amount of $\mathrm{MgCO}_{3}$ present in planktonic foraminifera.

Magnesium carbonate usually constitutes around $1 \%$ or less by weight in planktonic foraminiferal shells. The amount is apparently sufficient to play an important role in the relative dissolution among species. Savin and Douglas (in press) have established a strong negative correlation between the amount of $\mathrm{MgCO}_{3}$ incorporated in the test and the relative resistance to dissolution. Species with high $\mathrm{MgCO}_{3}$ values, such as Globigerinoides, are among the least preservable, whereas species with low $\mathrm{MgCO}_{3}$ values, such as Globorotalia, are among the most preservable. As a 
TABLE 1

Stratigraphic Distribution of Leg 17 Cores

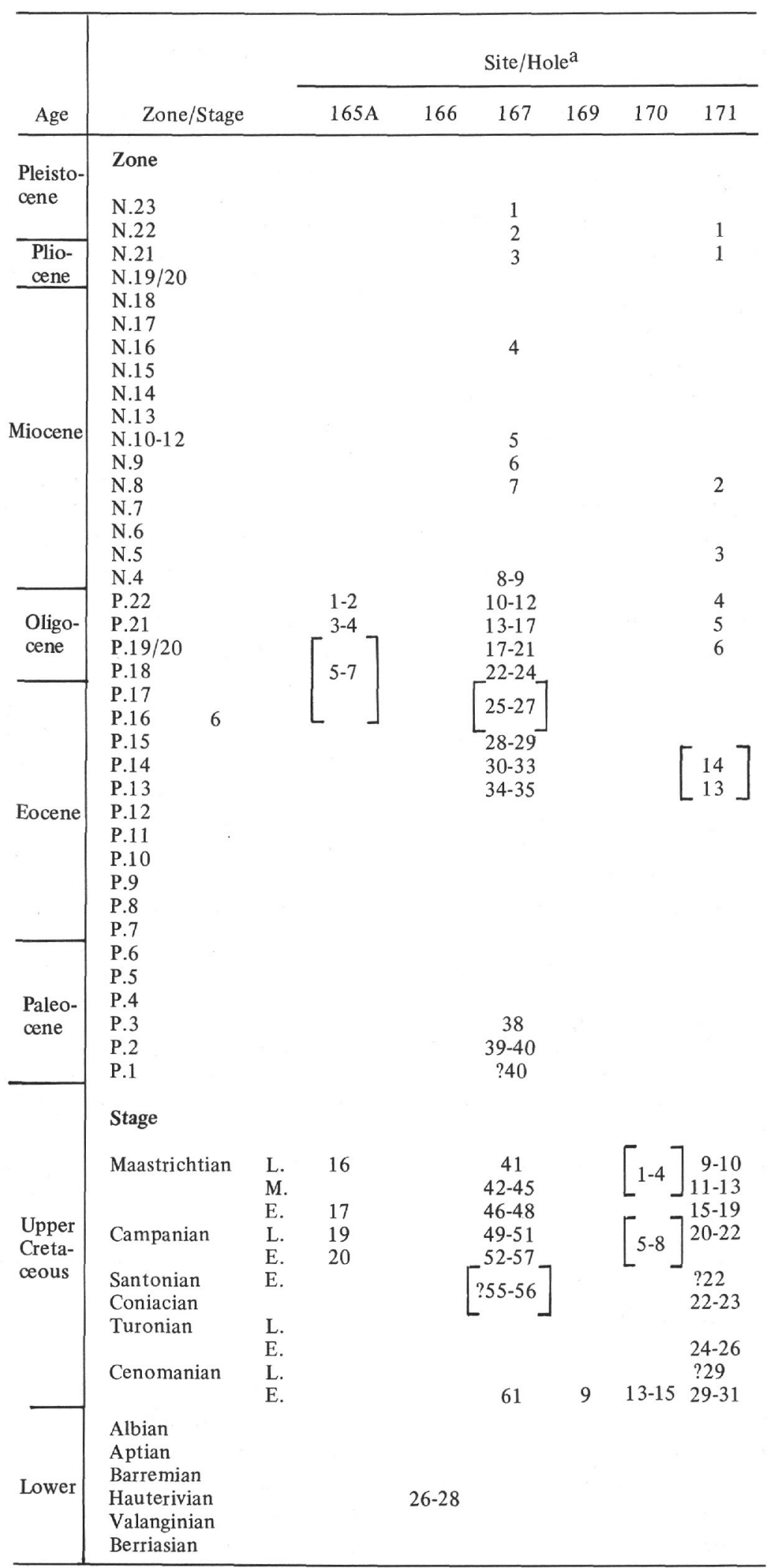

Note: Core distribution is based mainly on planktonic foraminifera.

aNo foraminifera recovered at Sites 164 and 168. 
further test of this relationship six middle Miocene (N. 12) species from the core catcher of Core 5, Site 167, were analyzed (Figure 2). The results are in good agreement with the amount of $\mathrm{MgCO}_{3}$ contained in Recent shells and the relative genus-species preservation ranking (Figure 3). The methods appear promising as a means for independently establishing the relative resistance of individual fossil species to solution.

\section{Foraminiferal Calcium Carbonate Loss}

The minimum loss in foraminiferal sediment assemblages due to dissolution can be estimated from the equation $\mathrm{L}=100\left(1-\mathrm{R}_{\mathrm{O}} / \mathrm{R}\right)$, where $\mathrm{L}$ is the loss necessary to increase the insoluble residue $R_{0}$ to $R$ percent, and by assuming that benthonic foraminifera are an insoluble component of the sediment assemblage (Berger, 1971). Benthonic species are, of course, soluble but they are more resistant to dissolution than planktonic species and provide a useful measure for understanding preservation in foraminiferal sediments.

In well-preserved, modern, deep-sea sediments planktonic species normally comprise more than $98 \%$ (usually around 99.5\%-99.9\%) of the total foraminiferal assemblage (Schott, 1935; Parker, 1954; Thiede, 1972) so that a small increase in the percentage of benthonic foraminifera may represent a large loss of planktonic foraminifera.

The calculated foraminiferal carbonate loss (L) values shown in Figures 4 and 5 assume that benthonic species originally comprised $0.2 \%\left(R_{0}\right)$ and that the increase in benthonic species $\left(R_{0} / R\right)$ is primarily due to selective dissolution. The latter assumption does not apply in cases where there has been current winnowing or downslope transport of sediment. These processes preferentially concentrate benthonic species with respect to planktonic species because they are thicker shelled and heavier. The resulting winnowed or transported assemblage may be similar to an assemblage created by selective dissolution. A distinct, but probably not unique, problem is created when benthonic species are redeposited into depths below the lysocline where sediment assemblages undergo considerable dissolution. A small addition of redeposited species may strongly affect both the planktonic/benthonic ratio and L. The interpretation of either measure requires consideration of relative abundance, preservation state, and the taxonomic composition of the fauna, as well as the bathymetric setting.
At Site 167 the value of $\mathrm{L}$ increases with increasing depth (Figure 4) below the sea floor and degree of lithification. Values range from 30 to $85 \%$ for oozes, 60 to $96 \%$ for Tertiary chalks, and over $90 \%$ for Cretaceous chalks and marly limestones. That is, even for so-called abundant and well-preserved assemblages in the upper 7 or 8 cores, on the average more than $50 \%$ of the planktonic foraminifera have been destroyed to account for the increased percentage of benthonic species. The $\mathrm{L}$ values for ooze are in good agreement with $\mathrm{L}$ values in recent sediments from comparable water depth and latitude (Parker and Berger, 1971) and similar sediment cores (Berger, 1971; Berger and von Rad, 1972). For chalks and marly limestone, the loss of planktonic foraminifera on the average is over $75 \%$ and up to $95 \%$ of the original sediment assemblage. Since benthonic species have been destroyed in the chalks and limestone due to dissolution and breakage, the actual destruction of planktonic species is underestimated by the value of $\mathrm{L}$.

Site 167 is located near the crest of the Magellan Rise; there is no source for redeposited benthonic species. The large percentage of less-than-44- $\mu$ fraction suggests there has been no winnowing. Thus the estimated foraminiferal loss based on the value of $\mathrm{L}$ is a reasonable measure of the diagenetic destruction that has occurred in planktonic foraminiferal assemblages during the processes of compaction and lithification.

At Site 171 , the values of $\mathrm{L}$ are greater than $90 \%$ for all the Tertiary cores (Figures 5 and 6), dropping to around $75 \%$ in the latest Cretaceous and increasing to over $90 \%$ below Core 19 (early Maastrichtian). The Cretaceous values correspond to increased dissolution of planktonic foraminifera and are reflected in the preservation and abundance curves. The Tertiary values appear to be anomalous, as planktonic foraminifera are both abundant and generally well-preserved in these cores. In the same samples, benthonic species range from $1.5 \%$ to over $5 \%$. Ostracods which normally occur in abundances of less than 5 values per sample, commonly exceed 50 valves per sample and approach 100 valves per sample. The ostracods and the presence of reworked foraminifera and Radiolaria suggest that the increased benthonic component is a result of redeposition. Site 171 is located in a saddle situated nearly 1,000 meters bathymetrically lower than the crest of the guyot. A comparison of Tertiary sediment assemblages at

\begin{tabular}{|c|c|c|c|c|}
\hline & $\begin{array}{c}\text { RECENT } \\
\text { (Savin and Douglas, } 19\end{array}$ & & MIOCENE & \\
\hline & & $\% \mathrm{MgCO}_{3}$ & & $\% \mathrm{MgCO}_{3}$ \\
\hline 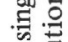 & Globigerinoides ruber & 0.62 & Globigerinoides quadrilobatus & 0.56 \\
\hline 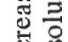 & G. sacculifer & 0.48 & Globoquadrina altispira & 0.33 \\
\hline$\Xi$. & G. conglobatus & 0.42 & Sphaeroidinellopsis seminulina & 0.36 \\
\hline & Globorotalia truncatulinoides & 0.37 & Globigerina venezuelana & 0.28 \\
\hline & G. cultrata & 0.37 & Globoquadrina dehiscens & 0.24 \\
\hline & G. tumida & 0.25 & Globorotalia fohsi & 0.23 \\
\hline
\end{tabular}

Figure 2. $\mathrm{MgCO}_{3}$ content of Middle Miocene species from Site 167. 
PLANKTONIC FORAMINIFERAL BIOSTRATIGRAPHY

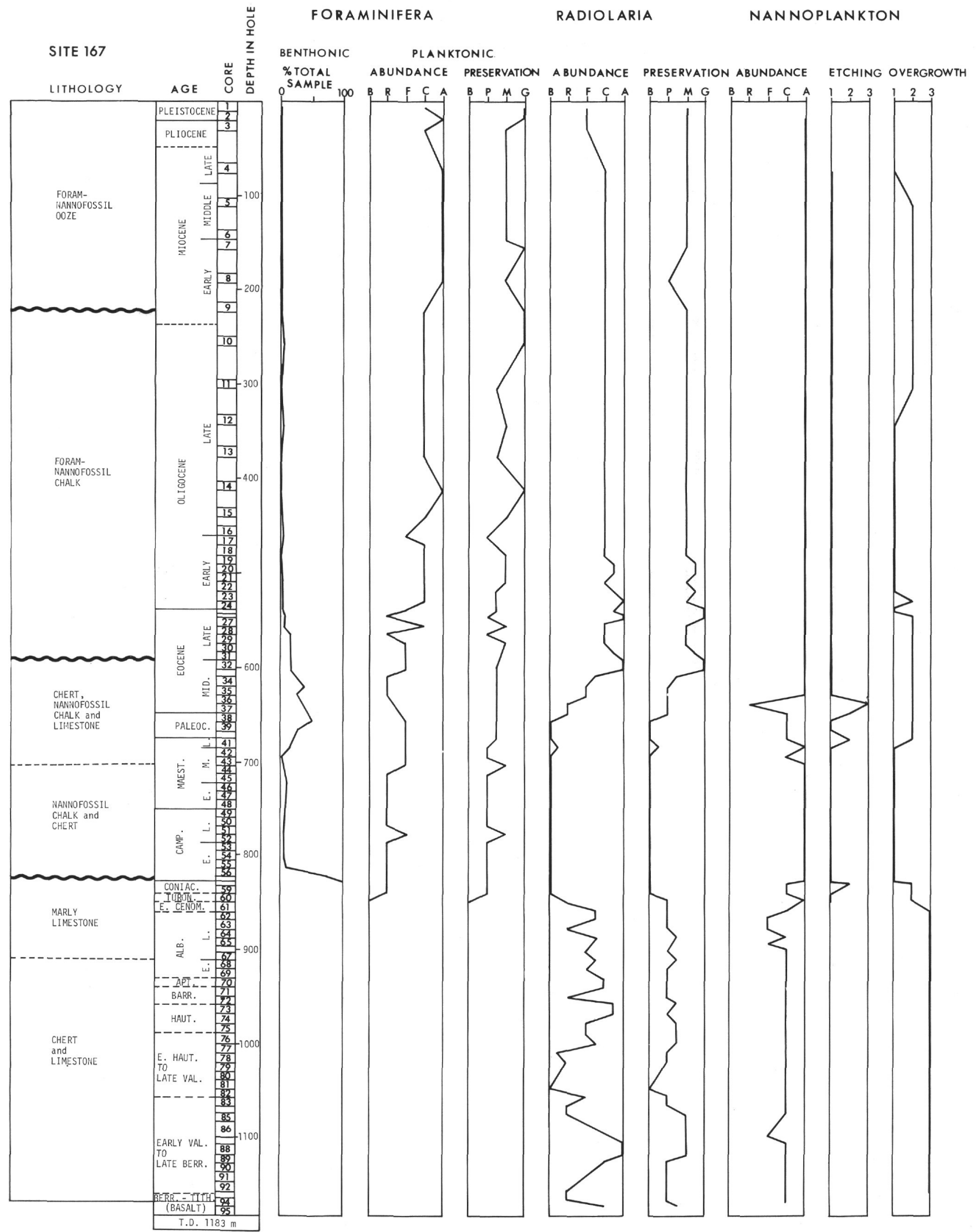

Figure 3. Comparison of the relative abundance and preservation of foraminifera, Radiolaria, and nannoplankton at Site 167. 
R. G. DOUGLAS

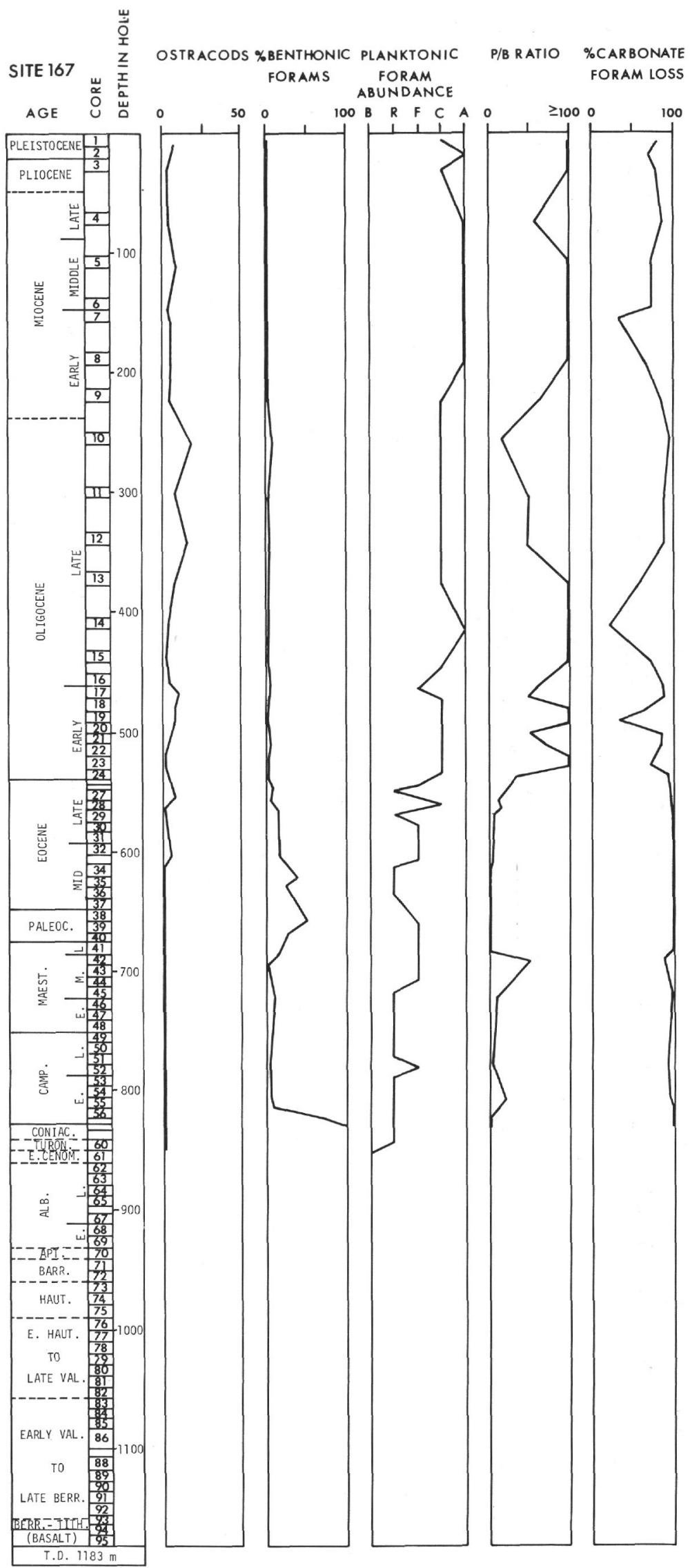

Figure 4. Abundance of planktonic and benthonic foraminifera, and ostracods, planktonic/benthonic ratio, and percent foraminiferal calcium carbonate loss due to dissolution at Site 167. 


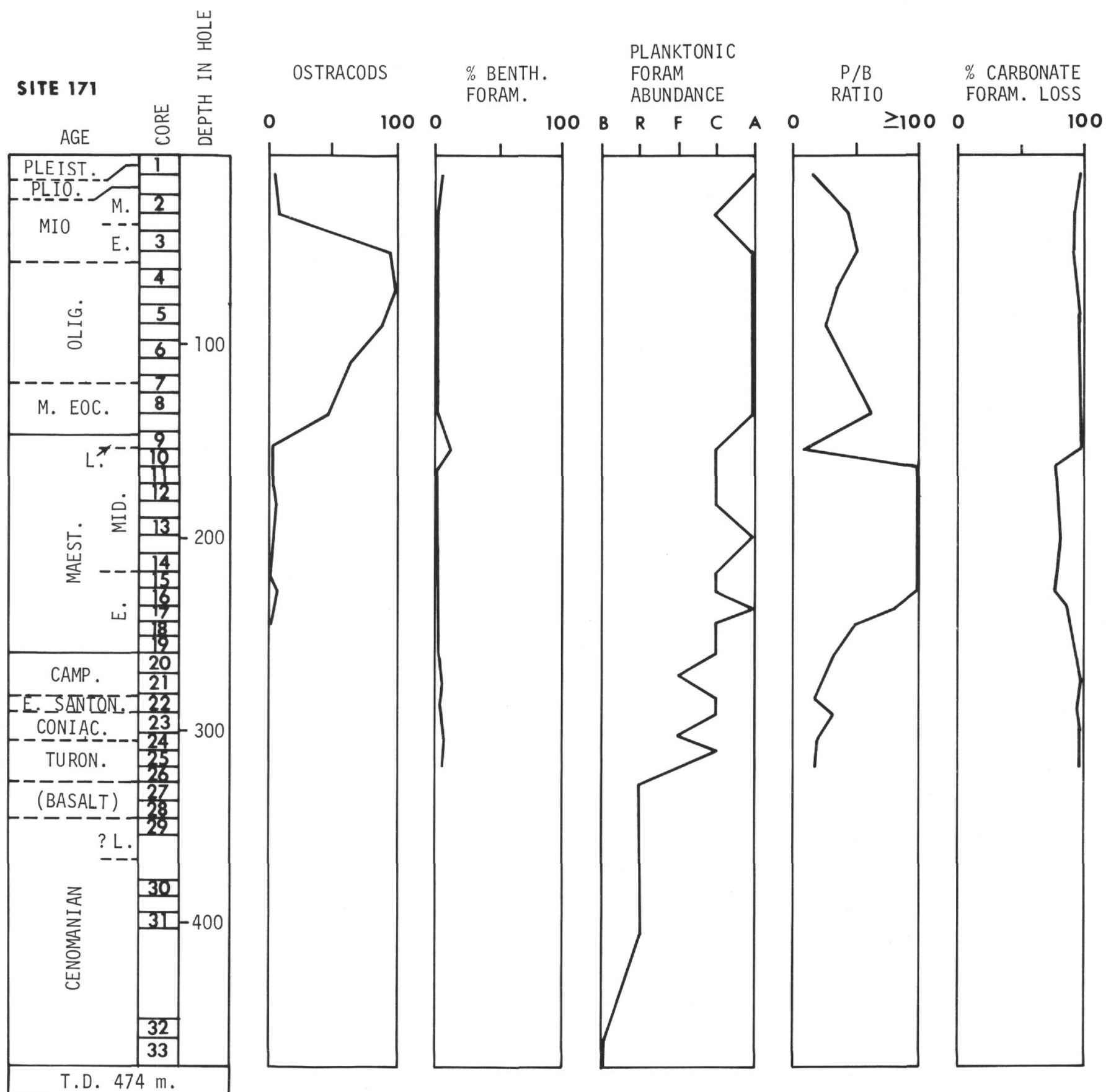

Figure 5. Abundance of foraminifera, and ostracods, planktonic/benthonic ratio, and percent of foraminiferal calcium carbonate loss due to dissolution at Site 171.

Sites 171 and 167 suggests, based on the state of preservation, that the amount of dissolution in planktonic foraminiferal assemblages at Site 171 is nearer 50\% than $90 \%$. If this is correct, redeposition has increased the benthonic component in the Oligocene samples by a factor of 2. The $\mathrm{L}$ values, number of ostracods, and benthonic foraminifera suggest that the high accumulation rate for the mid-Tertiary at Site 171 is due largely to redeposition of sediment. In contrast, the $\mathrm{L}$ values and ostracod numbers for the Cretaceous are about what one would expect for deep-sea biogenous sediments and are probably unaffected by redeposition.

\section{Planktonic/Benthonic Ratios}

The ratio of the number of planktonic to benthonic specimens ( $\mathrm{P} / \mathrm{B}$ ratio) is commonly used as a means for interpreting paleobathymetry (Grimsdale and van Morkhoven, 1955). A basic assumption is that the ratio 


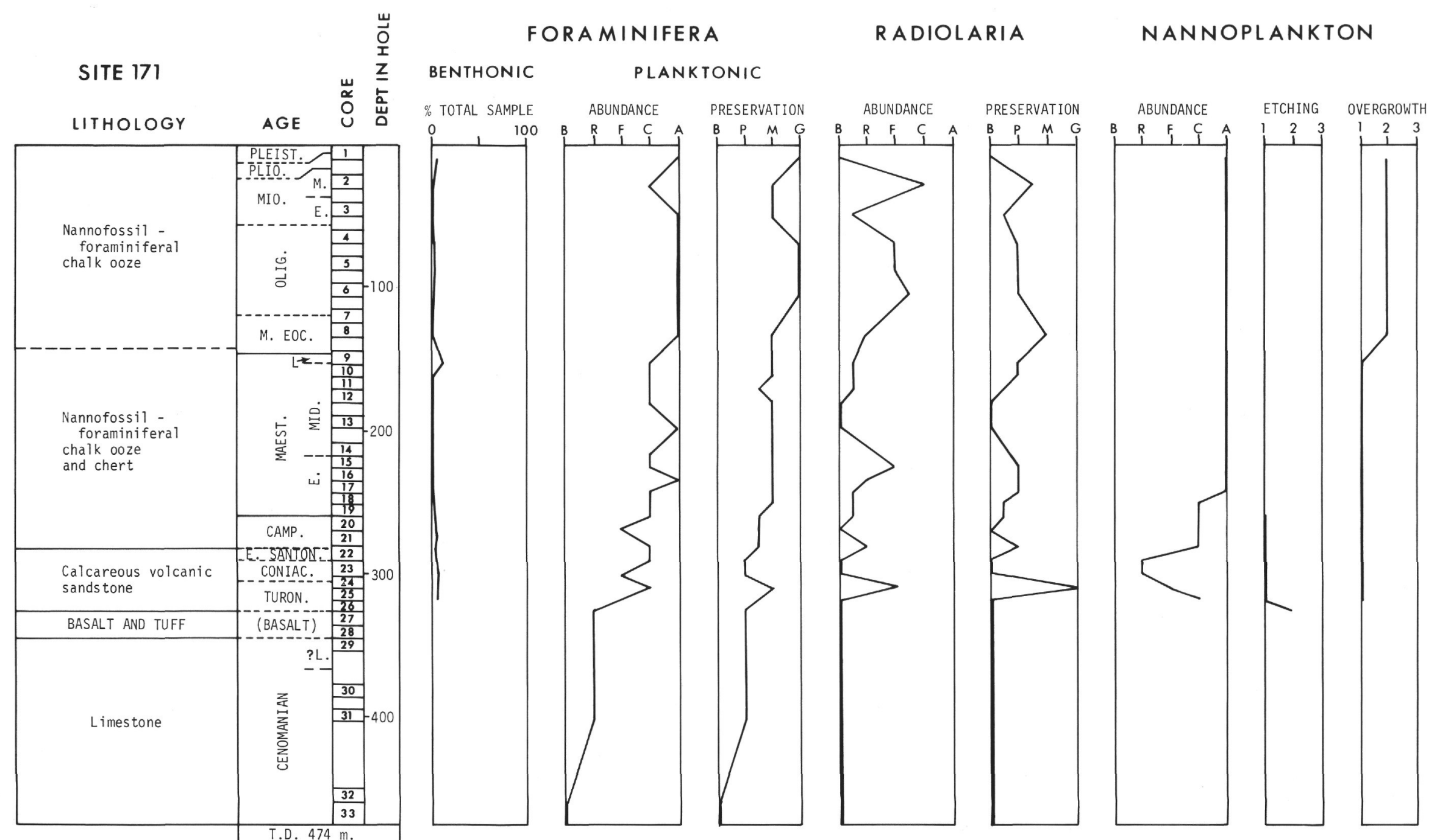

Figure 6. Comparison of the relative abundance and preservation of foraminifera, Radiolaria, and nannoplankton at Site 171. 
measures the original proportion of planktonic to benthonic foraminifera and that there has been little or no loss of either component. Recent studies of deep-sea sediments, however, indicate that the ratio is largely a function of preservation and is strongly affected by selective dissolution of foraminiferal tests during sedimentation (Berger, 1968; Parker and Berger, 1971).

The downhole diagensis of foraminifera at Site 167 affords an example of how the $\mathrm{P} / \mathrm{B}$ ratio is influenced by differential preservation of planktonic and benthonic species.

The value of the $\mathrm{P} / \mathrm{B}$ ratio varies largely with the abundance of planktonic foraminifera and thus decreases downsection in an irregular fashion as planktonic species are selectively destroyed relative to benthonic species (Figure 4). In fact, benthonic foraminifera are also being destroyed by breakage and dissolution, but at a slower rate so that the ratio always approaches zero as a limit. In the Neogene part of the section, P/B values greatly exceed 100 (generally around 200), whereas beginning in the Oligocene chalks, values drop to less than 150 and are mostly under 100. Below the Oligocene, all values are less than 30 . This rapid drop in $\mathrm{P} / \mathrm{B}$ values corresponds to the rapid increase in destruction of planktonic foraminifera that occurs below Core $24(540 \mathrm{~cm})$. It is evident that $\mathrm{P} / \mathrm{B}$ values derived for the chalk and limestone samples from Site 167 provide a good index of preservation, but have little relationship to paleodepth.

The P/B values at Site 171 also exhibit a strong influence of selective preservation but the down-hole trend in $\mathrm{P} / \mathrm{B}$ values is different than at Site 167 . The highest $P / B$ values occur not at the top of the section, as would be expected, but in the Cretaceous samples from between 160 meters and 245 meters. Tertiary values are less than 50 except for one core (Core $8,133 \mathrm{~m}$ ) although planktonic foraminiferal abundance is higher than in the Cretaceous part of the section. The low $\mathrm{P} / \mathrm{B}$ ratios for the Tertiary reflect the down-slope redeposition of sediment which has preferentially increased the numbers of benthonic microfossils.

\section{BIOSTRATIGRAPHIC SUMMARIES}

\section{Site 165, Hole 165}

The section cored at Hole 165 includes a thin sequence of nannofossil-radiolarian ooze. Foraminifera are sparse to common and generally moderately well-preserved, though many planktonic foraminifera exhibit solution pitting, holes, etc. There are benthonic foraminifera and rare occurrences of ostracods and fish debris in both cores recovered.

Core 1 contains a Miocene assemblage mixed with Pliocene species near the top of Section 1, middle Miocene in Sections 2 and 3, and lower Miocene in the core catcher. Core 2 contains late Oligocene assemblage with a mixture of Miocene and Quaternary derived from downhole caving in Section 2 and the core catcher. Most of the foraminifera in Core 2 are downhole contaminants.

\section{Site 165, Hole 165A (Table 2)}

The section cored at Hole $165 \mathrm{~A}$ consists of lower Tertiary nannofossil-radiolarian ooze with turbidite layers and upper Cretaceous calcareous turbidites and volcanic sediments resting on basalt. The Tertiary ooze contains rare to common Oligocene benthonic and planktonic foraminifera and varying amounts of reworked Maastrichtian, Paleocene, and Eocene foraminifera in the upper part (Cores 1-6) and is essentially devoid of foraminifera in the lower part (COres $7=15$ ). Rare benthonic and planktonic foraminifera, also with some reworked species, occur in the softer, more clay-rich Cretaceous turbidite layers (Cores 16, 17, 19, and 20).

Planktonic foraminifera are generally sparse, except in turbidite layers of Cores 1 to 5 where they are occasionally very abundant. Solution pitting, holes in the tests, and the absence of delicate, thin-walled species indicate that the fauna is largely a solution residue. This may explain in part the relatively uniform composition of the fauna. Species present in Cores 1, 2, and 3 correlate with the upper Oligocene (zones P.22 and P.21) and those in Core 5 with the lower Oligocene (zone P.20). The zonal boundary P.22/P.21 probably occurs between Core 2 and Core 3, but is difficult to delimit because of the irregular distribution of key species.

In cores 5 to 7 the planktonic foraminiferal assemblage consists of rare occurrences of Chiloguembelina, juvenile globigerines, and etched, thick-walled Globigerina and Globigerinita. They are late Eocene to early Oligocene in age. Cores 7 to 15 are devoid of foraminifera except for rare juvenile Globigerina and Chiloguembelina. Rare specimens of Globotruncana stuarti, G. aegyptiaca, and $G$. contusa identify the Abathomphalus mayaroensis Zone of the upper Maastrichtian in the core catcher of Core 16. All the species are "recrystallized" and most of the zonal species are missing. A few poorly preserved globotruncanids present in Core 17 are indicative of the early Maastrichtian to late Campanian but are insufficient to apply a zonal designation. The planktonic foraminifera recovered from the core catchers of Cores 19 and 20 total less than two dozen specimens, but include species of the G. stuartiformis Zone of middle to late Campanian age.

Reworked planktonic foraminifera occur throughout the Oligocene protions of the section. They are particularly numerous in Cores 1, 2, and 3 and include species from the upper part of the upper Cretaceous and middle and lower Eocene, and, at least in Core 3, the Paleocene. In the turbidite layers in Cores 4 to 7 , Cretaceous heterohelicids are mixed with Chiloguembelina and small globigerines in a size-sorted assemblage; no specimen is larger than about $125 \mu$.

Benthic remains are a minor but consistent part of the fauna in the Oligocene ooze and Maastrichtian turbidites. Most numerous are smaller benthonic foraminifera which are fairly abundant and well-preserved in Cores 2 and 3, but are distributed through most of the cored section (except Cores 9 through 15 and 18). Based upon the preservation state of the tests, the benthonic species appear to represent two sources. Most of the specimens from any given sample are well-preserved and are presumably contemporaneous with the deposit, though transported. A smaller number are usually recrystallized, etched, sometimes worn or broken, and appear to be derived from older deposits and different environments. The first group, those with a "fresh" 
TABLE 2

Range Chart of Cenozoic Planktonic Species at Sites 165 and 165A

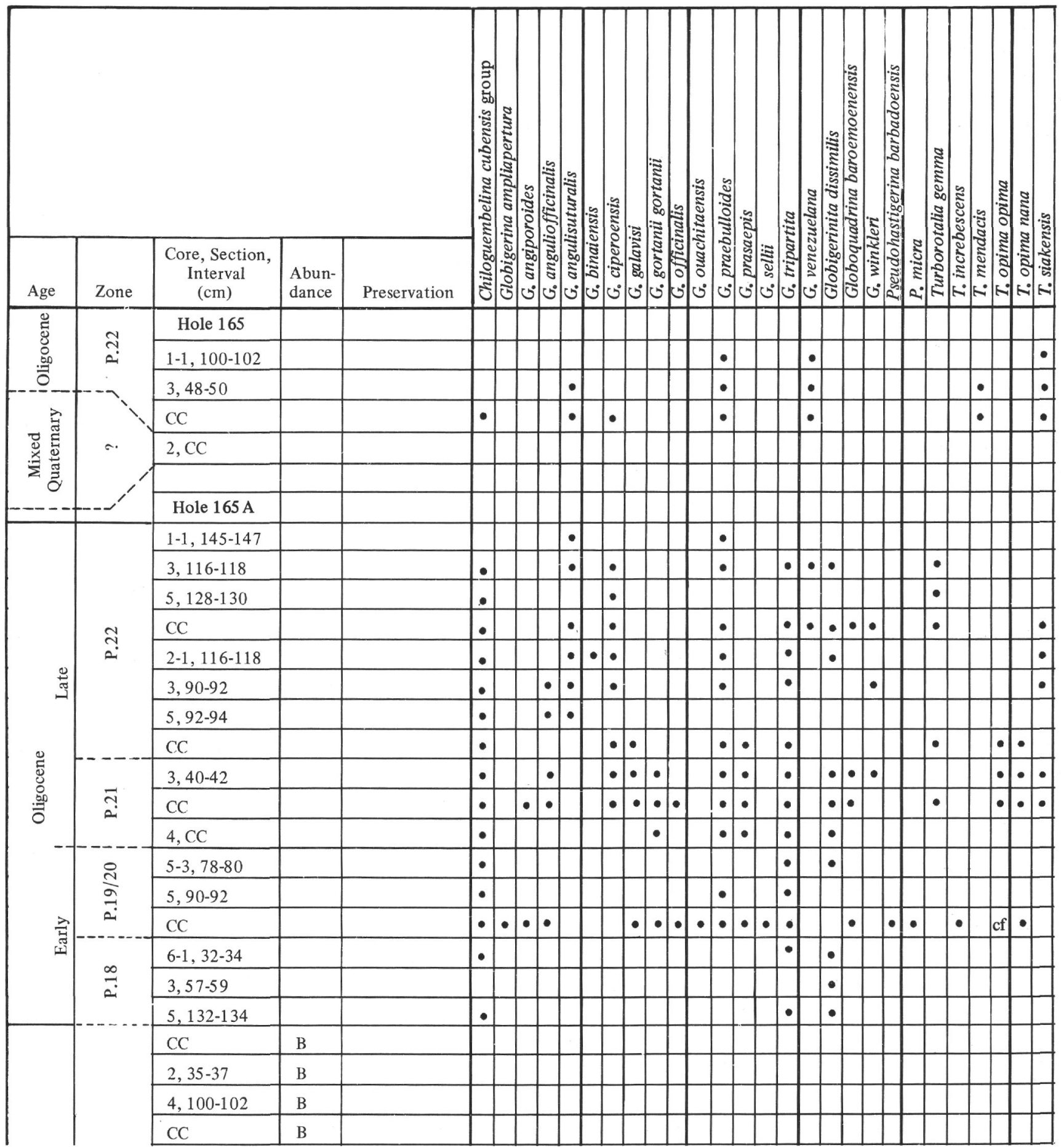

appearance, are typical of outer neritic/upper bathyal depths (based on generic identification). The second group is more difficult to define in terms of their original environment, but a few samples from Cores 2 and 3 include larger miliolids characteristic of inner neritic depths. Larger benthonic foraminifera occur at two intervals in the cored section, in Cores 2 and 3, and 17. They are usually associated with the "older," "recrystallized," smaller benthonic species and molluscan, bryozoan, and echinoid fragments. The genera in Cores 2 and 3 include Asterocyclina (middle to upper Eocene) and forms referred to Discocyclina. The Cretaceous species (Core 17) is tentatively identified as a pseudorbitoid. The large foraminifera indicate shallow-water reefal environments during the 
Middle-Late Eocene and Campanian-Maastrichtian in the Line Island Chain.

Ostracods, usually rare in pelagic deposits, are fairly numerous in Cores 3 , and rare in most of the samples that contain foraminifera. Mostly they are smooth bairdid or cypridid types, through a few ornamented species are present in Cores 3 .

\section{Site 166 (Table 3)}

Approximately 300 meters of section, consisting of Tertiary brown ooze and chert and Cretaceous chert and volcanic-rich sediments overlying basalt were drilled at Site 166. Foraminifera are rare in the recovered sediments and limited to three intervals: (1) a thin Quaternary layer at the

TABLE 3

Range Chart of Foraminiferal Species at Site 166

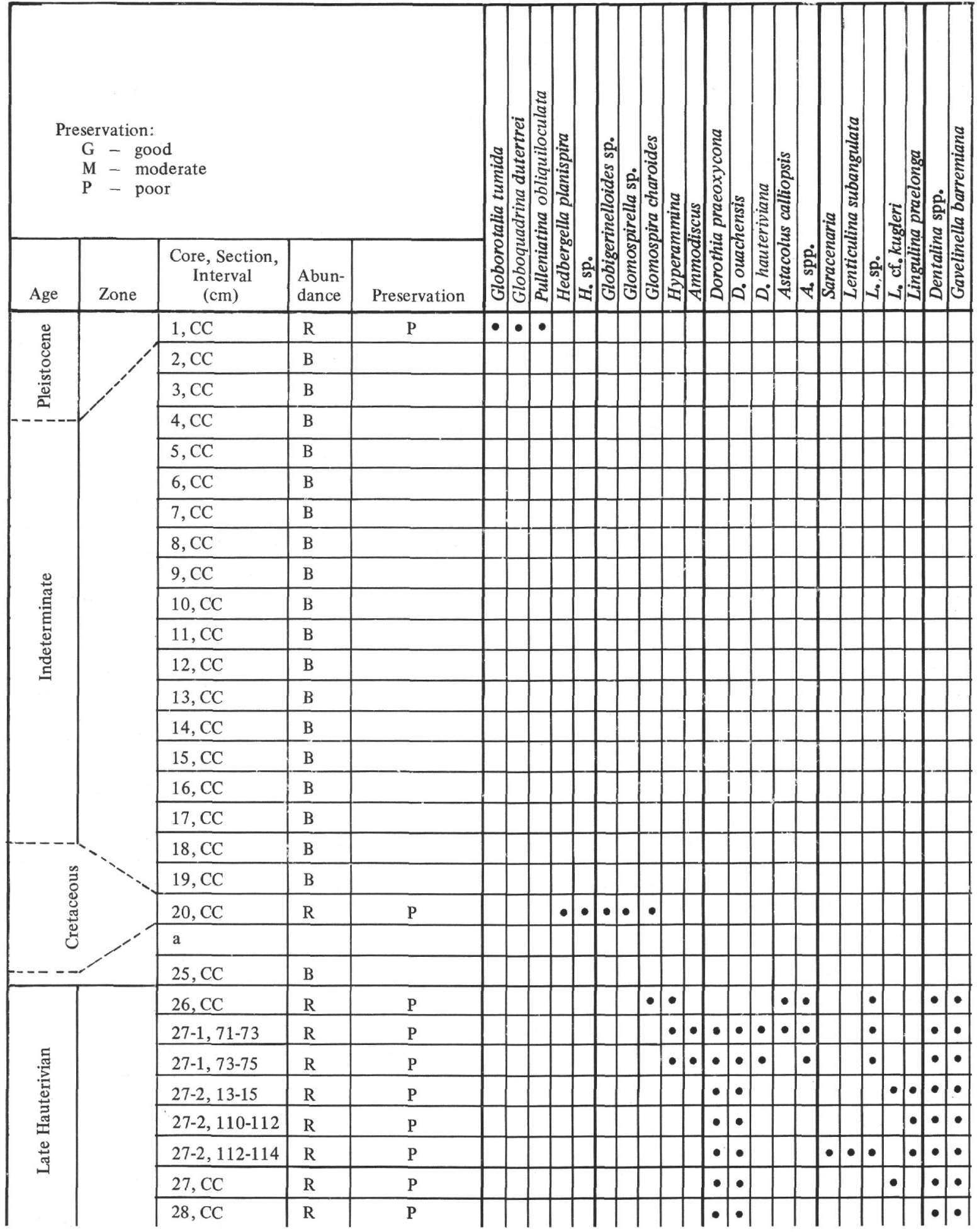

${ }^{\mathrm{a}}$ Cores 21-24 are barren. 
top of the section; (2) in the brown Miocene siliceous ooze: and (3) the early Cretaceous volcanic sediments near the bottom of the section.

The Quarternary assemblage in Hole 166-1, CC and Hole 166A-1-1, top part, is from a thin layer of carbonate ooze at or just below the sea floor. The assemblage consists of solution-resistant species, including Globorotalia tumida, Pulleniatina obliquiloculata, Globigerinoides sacculifer, Globigerinella siphonifera, and rare Globoquadrina dutertrei.

Below the Quarternary ooze foraminifera are missing between Cores 1 and 20, except for a few solution-resistant forms in Core 6, CC. Globoquadrina altispira, Globigerinita stainforthi, and Globigerina venzuelana suggest a Miocene age.

Cretaceous foraminifera occur in the dark-brown volcanic clay in Cores 20, 26, 27, and 28. In Core 20, foraminifera are rare and poorly preserved; most species appear to be silicified. A few broken specimens of Biticinella and Hedbergella spp. suggest that the core is Albian or Cenomanian in age and based on the Biticinella, probably Albian. The foraminifera in Cores 26, 27, and 28 are benthonic species, with displaced Tertiary planktonic species in Core 26. The most common taxa of the benthonic assemblage are smooth Lenticulina, Dentalina, Nodosaria, and the agglutinated foraminifer Dorothia ouchensis (Sigal). Fragments of a uniserial agglutinated species, possibly Ammobaculites, are sparse. Precise dating of the assemblage is difficult because of the lack of information about Cretaceous deep-sea foraminifera, but comparison with described species from Leg 1 and Leg 6 of the Deep Sea Drilling Project suggests the assemblage in Cores 26 and 27 is definitely Neocomian and probably Late Hauterivian. The faunule in Core 28 is poorly preserved and is dated as Neocomian. The most diagnostic species present in the three cores include Lenticulina cf. grata, $L$. muensteri, Astacolus calliopsis, A. cf. bronni, Nodosaria sceptrum, Dentalina debilis, and Gavelinella sp. All of the benthonic species are recrystallized, and many are broken or with holes. Well-preserved Albian Radiolarians recovered from Cores 26 and 27 suggest that the older Cretaceous foraminifera have been redeposited.

\section{Site 167 (Tables 4, 5, 6, and 7; Figure 4)}

A thick sequence of carbonate deposits, including much of the Tertiary and all the Cretaceous, was cored at Site 167. Foraminifera are limited to the upper two-thirds of the section (Cores 1-61), where they exhibit a progressive, through irregular change in abundance and preservation beginning in the Neogene and finally disappearing from the section in the Cenomanian (Figure 4). The change in abundance and preservation of foraminifera at Site 167 is concomitant with increasing lithification in the Tertiary and the change from foram-nannofossil ooze to foram-nannofossil chalk to radiolarian foram-nannofossil chalk to radiolarian-nannofossil chalk and limestone. Foraminifera disappear with the development of limestone in Cores 36 and 37. Foraminifera reappear in the section as the sediment becomes chalky in the Cretaceous and disappear again with the occurrence of limestone in Core 60. It is evident that the progressive loss of foraminifera is a product of dissolution, fragmentation, and cementation that accompanies the transition from ooze to chalk to limestone (see Chapter 13 , Schlanger et al., this volume).

Cores 1 and $2(0$ to $18 \mathrm{~m})$ are Quaternary (N.22/N.23) and contain a diverse fauna of planktonic and benthonic foraminifera. Globigerina calida calida is present with Sphaeroidinella dehiscens excavata near the bottom of Core 2. Globigerinoides quadrilobatus fistulosus, a marker of N.21, late Pliocene, occurs in Core 3. The assemblage in Cores 1,2, and 3 exhibits moderate signs of dissolution.

Spot-coring between 66 meters and 195 meters recovered portions of the upper, middle, and lower Miocene. Foraminifera are generally abundant in these cores (4 to 8) and moderately well-preserved. Near the top (Section 1, $70-72 \mathrm{~cm}$ ) of Core 4 rare specimens of Globigerinoides quadrilobatus fistulosus, indicative of lower N.17 were found but may be downhole cavings. Cores 5 and 6 contain diagnostic species of zones N.12 and N.9, middle Miocene, and Cores 7 and 8 of zones N.8 and N.4, respectively. The base of N.4 is placed at the bottom of Core 9 although Globigerinoides quadrilobatus primordius was not found in the core-catcher sample. Turborotalia kugleri is present only in the two lower sections (5 and 6) of Core 9 and suggests that the core is located toward the upper part of the zone. Samples from Cores 4 to 8 are nearly pure planktonic foraminifera (P/B ratios $>250$ :1) and benthonic species and ostracods are very rare. The zonal assemblages for the Miocene are particularly complete, especially in Cores 5 and 6.

Planktonic foraminifera in Cores 9 to 24 (223 to $560 \mathrm{~m}$ ) define a complete and apparently continuous sequence of Oligocene zones, P.22 to P.18. The assemblages in the upper zones are better preserved than those from the lower zones, and boundaries can be more closely defined between N.4/P.22 and P.22/P.21 than biostratigraphically lower horizons. Diagnostic species tend to have irregular distribution in Cores 16 to 24. For example, Globigerina angulisuturnalis is rare and poorly preserved beginning in Cores 15 and does not provide an adequate basis for defining the P.21/P.22 boundary. The "working" definition for the base of P.21 proposed by Beckmann (1971), namely the first occurrence of typical T. opima opima, was applied. Globigerina ciperonensis also has an irregular occurrence in the lower part of Zone P.22 and disappears entirely in the upper part of Zone P.19/20, well above the base of its stratigraphic range (Blow, 1969). In the lower Oligocene cores thick-walled species of Globigerina and Globigerinita dominate assemblages. The Eocene-Oligocene boundary is placed between Cores 24 and 25, which is in agreement with nannoplankton correlation. This placement is largely a matter of convenience because the highest occurrence of restricted Eocene species, Hantkenina primitiva, occurs in Core 27. Cores 25 and 26 contain undiagnostic assemblages.

Eocene planktonic foraminifera are poorly represented at Site 167. Core recovery was limited to partial cores (usually one or two sections) and core-catcher samples. Many samples contain very few foraminifera. Late (Cores 25-29) and middle (Cores 30-34) Eocene zones can be recognized, but the boundaries can only be approximately placed. Core 35 is highly contaminated with Neogene species derived from downhole cavings, and Cores 36 and 
TABLE 4

Range Chart of Neogene Planktonic Species at Site 167

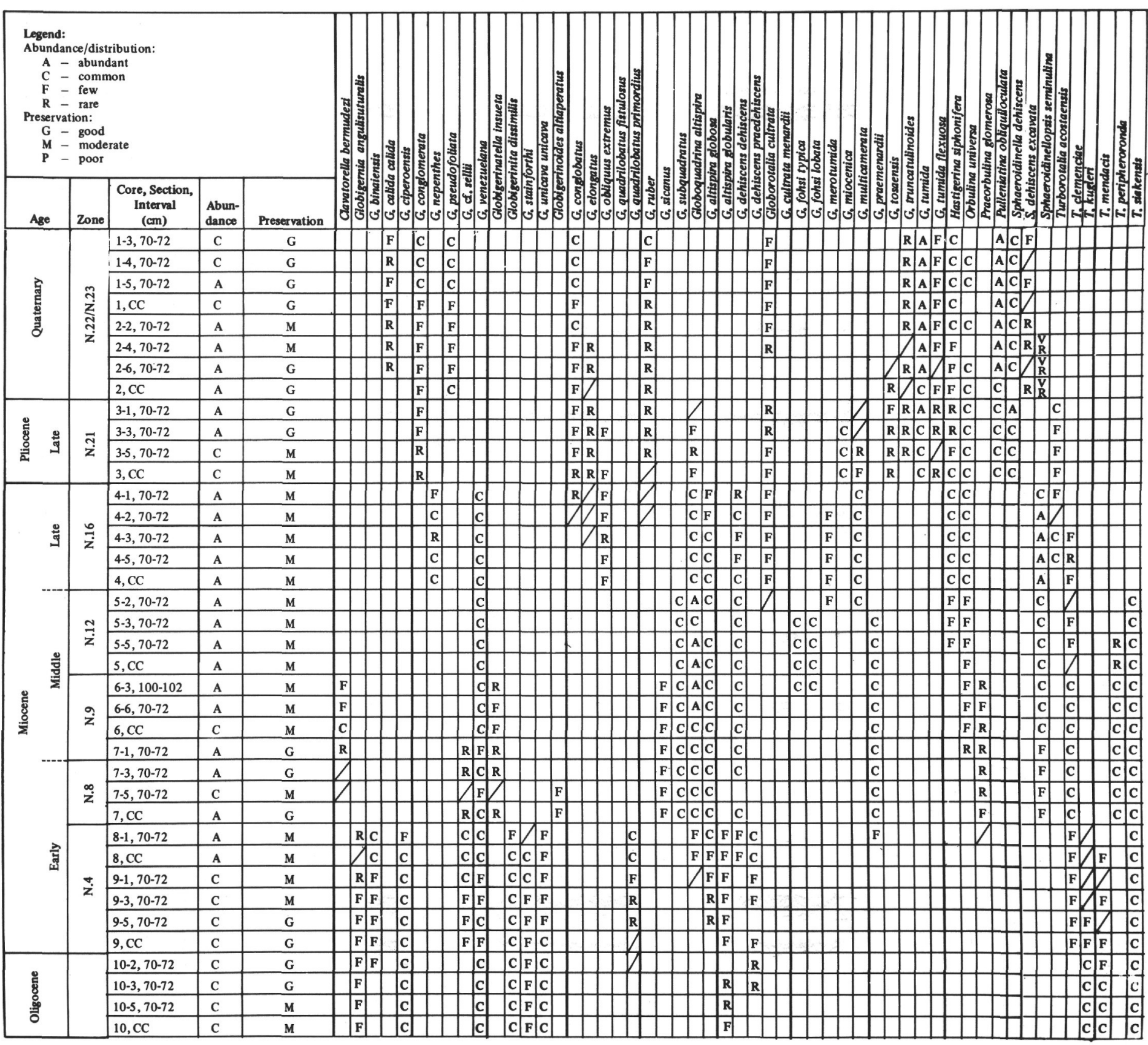


TABLE 5

Range Chart of Oligocene Planktonic Species at Site 167

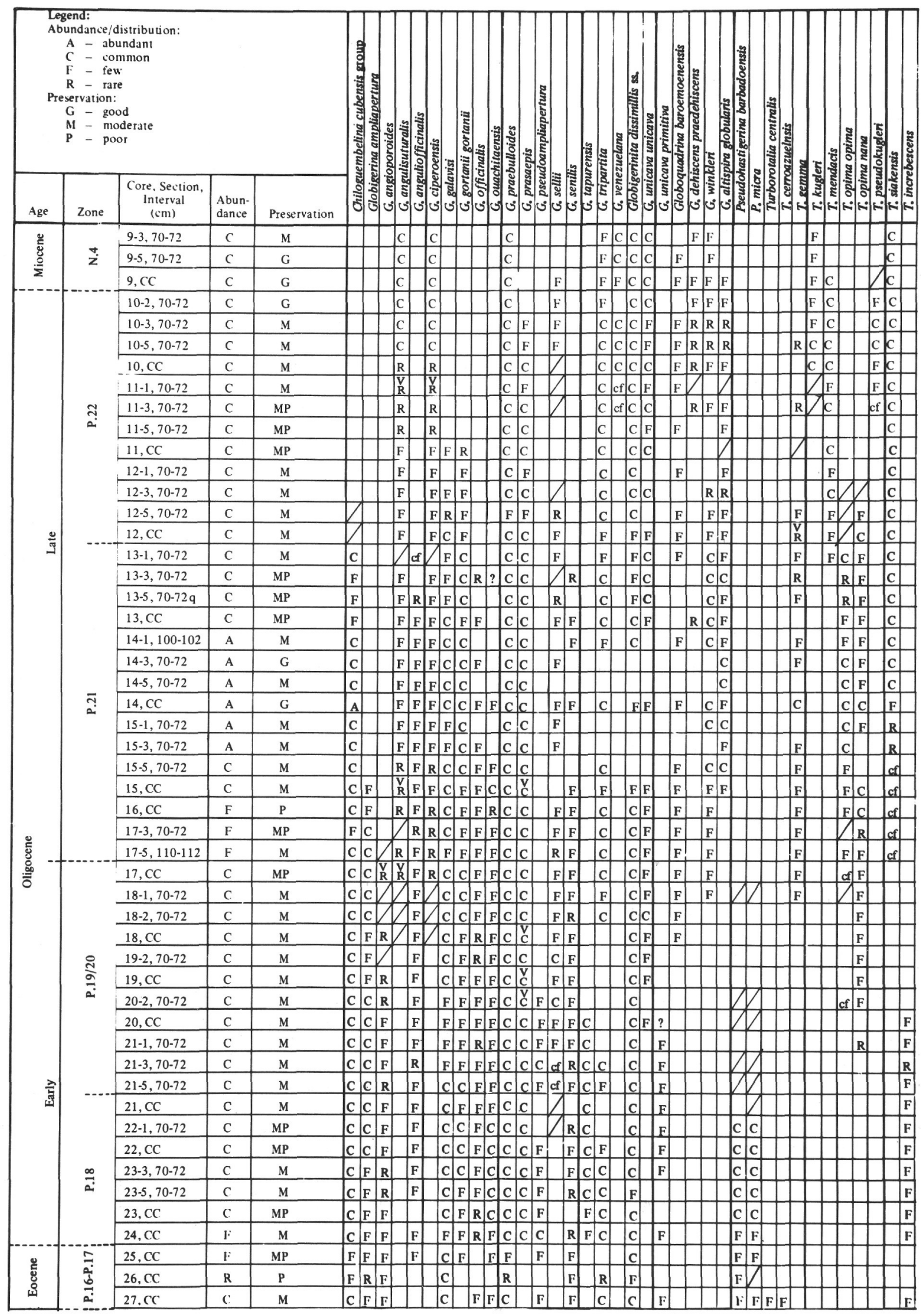


TABLE 6

Range Chart of Eocene and Paleocene Planktonic Species at Site 167

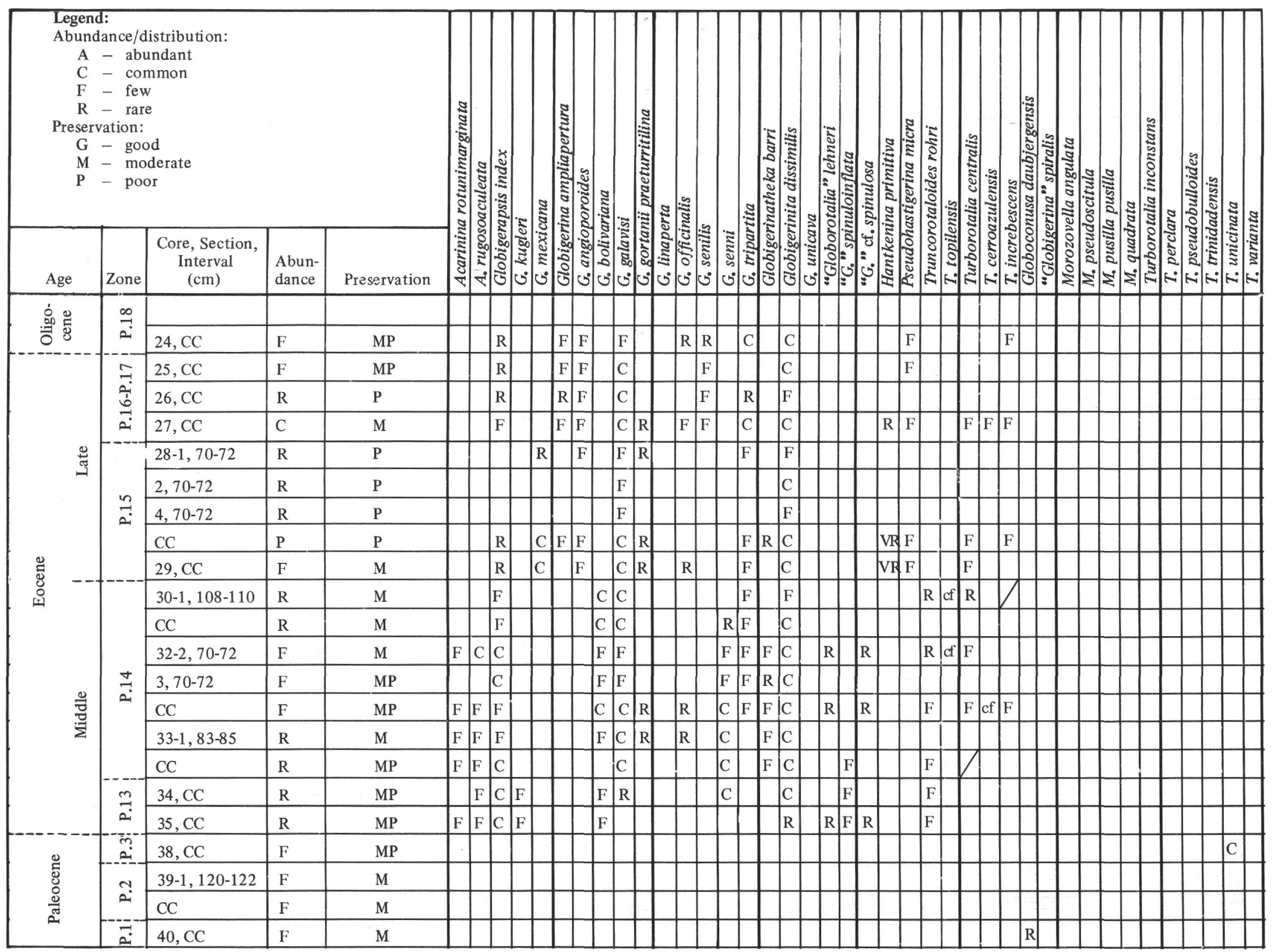


TABLE 7

Range Chart of Cretaceous Planktonic Species at Site 167

\begin{tabular}{|c|c|c|c|c|c|c|c|c|c|c|c|c|c|c|c|c|c|c|c|c|c|c|c|c|c|c|c|}
\hline \multicolumn{5}{|c|}{$\begin{array}{l}\text { Preservation: } \\
\begin{aligned} \mathrm{G}-\text { good } \\
\mathrm{M}-\text { moderate } \\
\mathrm{P}-\text { poor }\end{aligned}\end{array}$} & \multirow{2}{*}{ 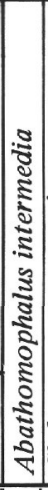 } & \multirow{2}{*}{ 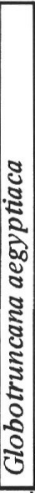 } & & \multirow{2}{*}{ 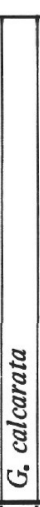 } & \multirow{2}{*}{ 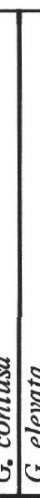 } & \multirow{2}{*}{5} & \multirow{2}{*}{$\begin{array}{l}5 \\
\mathbf{5} \\
\tilde{5} \\
5 \\
5 \\
0 \\
0\end{array}$} & \multirow{2}{*}{ 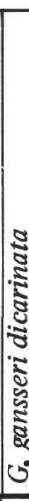 } & \multirow{2}{*}{ 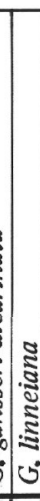 } & \multirow{2}{*}{ 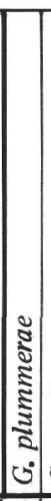 } & \multirow{2}{*}{ 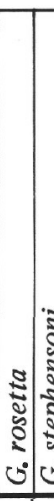 } & \multirow{2}{*}{ 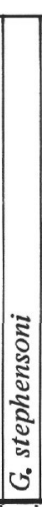 } & \multirow{2}{*}{ 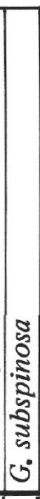 } & \multirow{2}{*}{ 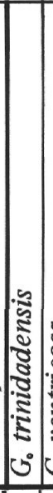 } & 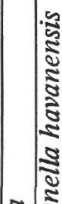 & 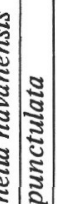 & & 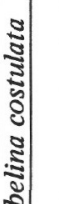 & 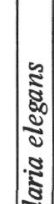 & & 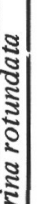 & 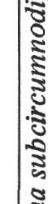 & \\
\hline Age & Zone & $\begin{array}{l}\text { Core, Section, } \\
\text { Interval } \\
(\mathrm{cm}) \\
\end{array}$ & $\begin{array}{l}\text { Abun- } \\
\text { dance }\end{array}$ & Preservation & & & $\begin{array}{l}5 \\
5 \\
5 \\
5 \\
5\end{array}$ & & & & & & & & & & & & 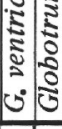 & 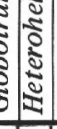 & 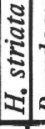 & 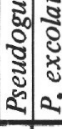 & 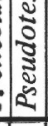 & 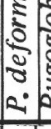 & 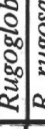 & 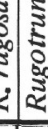 & 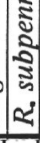 \\
\hline & & $41, \mathrm{CC}$ & $F$ & $\mathrm{P}$ & $\bullet$ & $\bullet$ & $\bullet$ & T. & - & & $\bullet$ & $\bullet$ & & & & $\bullet$ & & & & $\bullet$ & & • & & $\bullet$ & $\cdot$. & - & \\
\hline 莺 & อั & $42-1,56-58$ & $\mathrm{~F}$ & $\mathrm{P}$ & - & $\bullet$ & $\bullet$ & & - & & & • & & & & • & & & & $\bullet$ & & - & & & $\cdot$ & - & \\
\hline & $\vec{\Xi}$ & $42-3,70-72$ & $\mathrm{C}$ & $\mathbf{P}$ & & - & $\bullet$ & & - & & & & & & & - & & & & & & $\bullet$ & & -1 & $\bullet$ & • & \\
\hline & $+\dot{\nabla}$ & $42-5,70-72$ & $\mathrm{~F}$ & $\mathrm{P}$ & - & - & $\bullet$ & 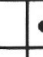 & $\bullet$ & & . & . & & & & $\bullet$ & & & & & $\bullet$ & $\cdot \bullet$ & & $\cdot$ & & & \\
\hline & & $42, \mathrm{CC}$ & $\mathrm{F}$ & $\mathrm{P}$ & & $\bullet$ & $\bullet$ & & - & & $\bullet$ & & $\bullet$ & & & $\bullet$ & & $\bullet$ & & & $\bullet$ & $\bullet \bullet$ & & - & & $\bullet \bullet$ & \\
\hline ㅍ & & $43-2,20-22$ & $\mathrm{~F}$ & $\mathrm{M}$ & & $\bullet$ & -1 & 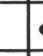 & $\bullet$ & & & & $\bullet$ & & & - & & & & & & & & & 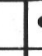 & 5 & \\
\hline 窇 & & $43, \mathrm{CC}$ & $\mathrm{F}$ & $\mathrm{M}$ & & $\bullet$ & $\bullet$ & 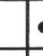 & - & - & - & & $\bullet$ & & & - & & & $\bullet$ & • & & & & & 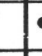 & $\bullet$ & \\
\hline 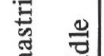 & 苟 & $44-1,124-126$ & $\mathrm{R}$ & $\mathrm{P}$ & & & $\bullet$ & & & • & & & $\bullet$ & & & - & & - & $\bullet$ & $\bullet$ & & $\bullet$ & & & & & \\
\hline$\sum^{\pi} \quad$ & 莣 & $44, \mathrm{CC}$ & $\mathrm{R}$ & $P$ & & - & - & & - & $\bullet$ & $\bullet$ & & $\bullet$ & & & $\bullet$ & & & $\bullet$ & - & $\bullet$ & $\bullet$ & & & & & \\
\hline & $ن^{\circ}$ & $45-3,130-132$ & $\mathrm{R}$ & $\mathrm{P}$ & & & - & & - & $\bullet$ & & & - & & & - $\bullet$ & & & $\bullet$ & $\bullet$ & 7 & & & & & + & \\
\hline & & $45-6,70-72$ & $\mathrm{R}$ & $\mathrm{P}$ & & & - & & - & $\bullet$ & & & - & & & - $\bullet$ & & & $\bullet$ & - & $\cdot$ & $\bullet$ & & & & & \\
\hline & & $45, \mathrm{CC}$ & $\mathrm{R}$ & $P$ & $\bullet$ & & - & & - & & cf & & 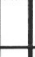 & & & $\bullet$ & & 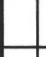 & $\bullet$ & $\cdot$ & 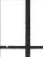 & & $\bullet$ & & & $\bullet$ & $\bullet$ \\
\hline & : & $46, \mathrm{CC}$ & $\mathrm{R}$ & $\mathbf{P}$ & & & - & & $\bullet$ & $\bullet$ & & & $\bullet$ & & & $\bullet$ & & $\bullet$ & 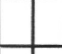 & & $\bullet$ & $\bullet$ & & & & & $\bullet$ \\
\hline 氞 & ฐิ & $47, \mathrm{CC}$ & $\mathrm{R}$ & $\mathbf{P}$ & & & - & & $\bullet$ & $\bullet$ & & & & & & $\bullet$ & & $\bullet$ & $\bullet$ & - & $\bullet$ & - & & & & & 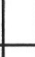 \\
\hline & -2 & $48, \mathrm{CC}$ & $\mathrm{R}$ & $P$ & & & - & & & & & & 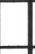 & & & $\bullet$ & & & & & & & & & & - & $\bullet$ \\
\hline & & 49-1 & $\mathrm{R}$ & $\mathbf{P}$ & & & & - & & $\bullet$ & & & $\bullet$ & & & & & & $\cdot$ & & - & & & & & & \\
\hline & $\frac{2}{8}$ & $49, \mathrm{CC}$ & $\mathrm{R}$ & $\mathbf{P}$ & & & $\bullet$ & - & $\bullet$ & $\bullet$ & & & & & - & $\bullet$ & $\bullet$ & & - & & $\bullet$ & $\bullet$ & & & & & \\
\hline 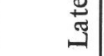 & కูป & $50-1,100-102$ & $\mathrm{R}$ & $\mathrm{P}$ & & & - & & & • & & & & & & $\bullet$ & & & & & & & & & & & \\
\hline & 8 & $50, \mathrm{CC}$ & $\mathrm{R}$ & $\mathbf{P}$ & & & - & $\bullet$ & & & & & $\cdot$ & & & • & & & & & $\bullet$ & & & & & & \\
\hline & & $51, \mathrm{CC}$ & $\mathrm{F}$ & M & & & - & - & • & $\bullet$ & & & $\cdot 1$ & - & - $\bullet$ & - $\bullet$ & $\bullet$ & $\cdot$ & $\cdot$ & & $\cdot$ & $\bullet$ & $\bullet$ & & & & \\
\hline & & $52-1,70-72$ & $\mathrm{R}$ & $\mathrm{P}$ & & & 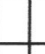 & & & $\bullet$ & & & $\cdot$ & & & $\bullet$ & & & & & $\cdot$ & & & & & & \\
\hline . & & $52, \mathrm{CC}$ & $\mathrm{R}$ & $\mathrm{P}$ & & & $\bullet$ & & & $\bullet$ & & & $\bullet$ & & & $\bullet$ & & & & & $\cdot$ & - & & & & & \\
\hline స్్ㅠ. & & $53-1,88-90$ & $\mathrm{R}$ & $\mathrm{P}$ & & & - & & & - & & & $\bullet$ & & & $\bullet$ & & & & & $\cdot$ & & & & & & \\
\hline Eี & 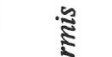 & $53, \mathrm{CC}$ & $\mathrm{R}$ & $\mathrm{P}$ & & & - & & & $\bullet$ & & & $\cdot$ & & & $\bullet$ & & & & & $\bullet$ & $\bullet$ & & & & & \\
\hline$\vec{z}$ & $\frac{2}{2}$ & $54-1,130-131$ & $\mathrm{R}$ & $\mathrm{P}$ & & & $\cdot$ & & & $\bullet$ & & & - & & & $\bullet$ & & & & & $\bullet$ & & & & & & \\
\hline I & కิ & $54, \mathrm{CC}$ & $\mathrm{R}$ & $\mathrm{P}$ & & & $\bullet$ & & & $\bullet$ & & & $\cdot$ & & & $\bullet$ & & & & & $\bullet$ & & & & & & \\
\hline & j" & $55-2,46-48$ & $\mathrm{R}$ & $\mathrm{P}$ & & & & & & & & & & & & & & & & & - & & & & & & \\
\hline & & $55, \mathrm{CC}$ & $\mathrm{R}$ & $\mathrm{P}$ & & & $\bullet$ & & & $\bullet$ & & & $\bullet$ & & & $\bullet$ & & & & & $\bullet$ & & & & 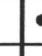 & $\cdot$ & \\
\hline & & $56-1,82-84$ & $\mathrm{R}$ & $\mathrm{P}$ & & & & & & & & & & & & & & & & & & & & & & & \\
\hline & & $56, \mathrm{CC}$ & $\mathrm{R}$ & $\mathbf{P}$ & & & - & & & - & & & & & & $\bullet$ & & & & & $\bullet$ & & & & & & \\
\hline & a. & $57-1,45-47^{a}$ & $\mathrm{R}$ & $\mathrm{P}$ & & & & & & & & & & & & & & & & & & & & & & & \\
\hline & & $57, \mathrm{CC}^{\mathrm{a}}$ & $\mathrm{R}$ & $\mathrm{P}$ & & & & & & & & & & & & & & & & & & & & & & & \\
\hline
\end{tabular}

${ }^{a}$ Only Benthonic species. 
37 are barren of foraminifera. Early Eocene foraminifera were not found.

Paleocene assemblages of foraminifera occur in Cores 38, 39, and 40. All three cores also contain Neogene species, in fairly large numbers in Core 40. Rare Cretaceous species occur in Core 39, core catcher, and in Core 40. The Neogene species are believed to be from downhole cavings and the Cretaceous species appear to be reworked. Younger Paleocene zonal markers have been downmixed into older assemblages in all three cores but sufficient numbers of stratigraphically restricted species are present to identify portions of zones P.3 (Core 38) and P.2 (Core 39). Core 40 contains a mixed P.3-P.2 fauna and perhaps earlier Danian elements as well. Because of poor core recovery and the downmixing of species, it is impossible to determine the exact stratigraphy of the drilled interval between the bottom of Core 37 and the top of Core 41. It seems likely that a hiatus occurs between the Eocene and Paleocene. The presence of Cretaceous species in the core catcher of Core 39 and in Core 40 suggests that either the CretaceousTertiary boundary is an erosional contact and the species reworked, or that the Cretaceous was penetrated in Core 39 but only downhole cavings from the Paleocene were recovered.

Of the 53 Cretaceous cores recovered, 19 contain foraminifera. They are, however, characterized by poor preservation and sparse assemblages. Species of the late Maastrichtian Abathomphalus mayaroenses Zone are present in Cores 41 and 42 , and the rare occurrence of Globotruncana gansseri and $G$. aegyptiaca suggests that Cores 43 to 45 are assignable to the $G$. gansseri Zone. Cores 46 to 48 are assigned to the Rugotruncana subcircumnodifer Zone based on scattered occurrences of the nominate species and the principle of superposition. The presence of $G$. calcarata, together with $G$. subspinosa, indicates Cores 49 to 51 are latest Campanian. Lower cores (52 to 55) contain a sparse assemblage of $G$. arca, $G$. fornicata, G. stuartiformis, and Heterohelix striata. Planktonic foraminifera are absent except for rare recrystallized forms below Core 55 .

\section{Site 168}

No foraminifera were found in the section drilled at Site 168 except for a few poorly preserved, solution-resistant species in the core "sock" of Core 1. These species included Globigerinita glutinata and fragments of other Globigerina and unidentifiable Globorotalia of probable Quarternary or Late Neogene age.

\section{Site 169 (Table 8)}

Foraminifera occur in two cores (2 and 9) out of the 11 cores drilled at Site 169 .

In Core 2 there are a small number of agglutinated specimens of the genera Bathysiphon, Saccammina, Hyperammina, and Haplophragmoides. No calcareous species were found in the core sample.

Core 9 contains a few well-preserved, although recrystallized, planktonic species, including Rotalipora evoluta, $R$. sp., Planomalina cf. buxtorfi, Hedbergella trocoidea, of the $R$. evoluta Zone, lower Cenomanian.

\section{Site 170 (Table 9)}

Foraminifera occur in 7 of the 16 cores drilled at Site 170 and are restricted to the nannofossil ooze and soft limestone. All of the foraminifera recovered are Cretaceous in age and include species from portions of the Maastrichtian, Campanian, Cenomanian, and perhaps the Albian.

A mixed lower Maastrichtian assemblage, containing predominantly Rugotruncana subcircumnodifer Zone species, is found in Core 3. A few upper Maastrichtian species, such as Globotruncana conica and $G$. trinidadensis, suggest that the top of the stage was penetrated in the interval between 15 and 74 meters below bottom. Preservation is moderate to poor and only large globotruncanids and rare large rugoglobigerines were found in the corecatcher sample. It is, however, the richest assemblage recovered in the section.

Planktonic foraminifera of probable Campanian age occur in Cores 5, 6, and 7. The assemblages appear to be size sorted, and specimens larger than about $100 \mu$ are very rare. Common taxa include juvenile and small species of Heterohelix, Globotruncana, Pseudoquembelina, Globigerinelloides, Schackoina, and reworked species of Hedbergella. Rare Cenomanian or Albian species occur in Core 7.

The zeolitic clay of Cores $8,9,10,11$, and 12 are barren.

The lower part of the section contains a sparse Early Cenomanian (Rotalipora evoluta Zone) assemblage which includes the diagnostic species Rotalipora evoluta, $R$. appenninica, Praeglobotruncana delrioensis, and $P$. bronnimanni in Core 13 and small Hedbergella and Globigerinelloides spp. and Heterohelix washitaensis in Cores 14 and 15. Preservation is moderate.

\section{Site 171 (Tables 10, 11, and 12)}

The stratigraphic sequence at Site 171 includes Tertiary oozes, upper Cretaceous chalk, glauconitic chalks, volcanic rocks, and a 125-meter interval of undated limestone.

The Tertiary portion of the hole was pot-cored, and recovery was limited to the Quaternary, middle and lower Miocene (zones N.8 and N.5, respectively); Oligocene (zones P.22, P.21, and P.19/20); and middle Eocene (zones P.14-13). Core 7, between 115 and 124 meters, contained insufficient material to process for foraminifera, but nannofossils date the core as Oligocene. Reworked lower Eocene planktonic foraminifera occur in Core 5. A well-developed middle Eocene (P.14-P.13) fauna is contained in Core 8 and the upper four sections of Core 9. The middle Eocene rests uncomfortably upon the Maastrichtian, and the lower part of the Paleogene and very top of the Maastrichtian are missing. Abundant early Eocene and lesser numbers of Paleocene and Maastrichtian species are reworked in the middle Eocene cores. Some Eocene species are downmixed into the Cretaceous in the lower part of Core 9.

Planktonic and benthonic foraminifera are common to abundant, and preservation is good except in Core 2 . Ostracods are sparse but occur in nearly all of the Tertiary samples examined.

Cretaceous foraminifera are present in Cores 9 through 26 and Core 29, between about 148 and 357 meters. 
TABLE 8

Range Chart of Planktonic Species at Site 169

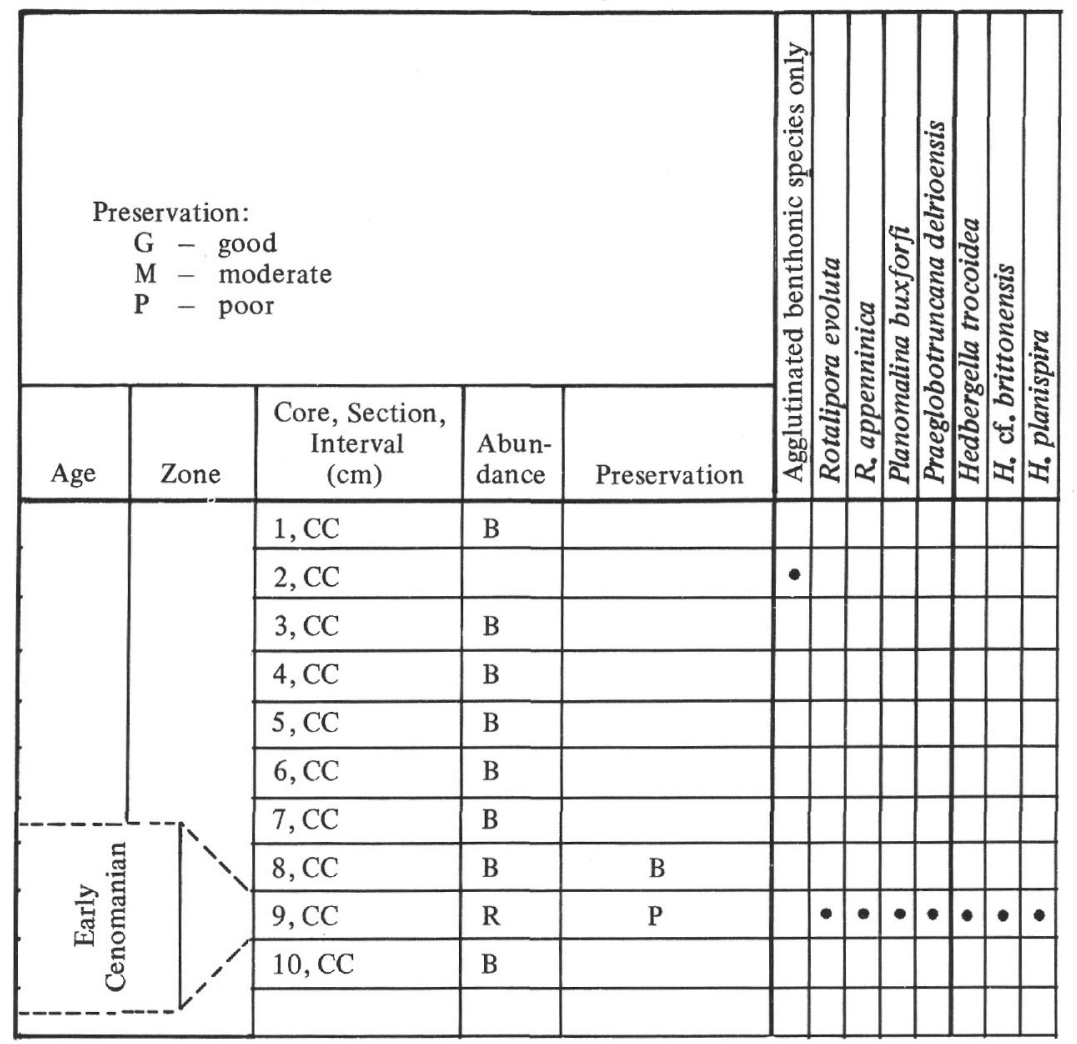

TABLE 9

Range Chart of Planktonic Species at Site 170

\begin{tabular}{|c|c|c|c|c|c|c|c|c|c|c|c|c|c|c|c|c|c|}
\hline \multicolumn{5}{|c|}{$\begin{array}{l}\text { Preservation: } \\
\begin{array}{l}\mathrm{G}-\text { good } \\
\mathrm{M}-\text { moderate } \\
\mathrm{P}-\text { poor }\end{array}\end{array}$} & \multirow{2}{*}{ 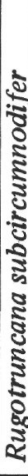 } & \multirow{2}{*}{ 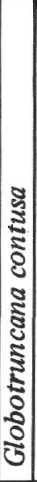 } & \multirow{2}{*}{ 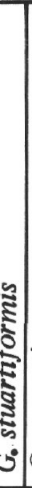 } & \multirow{2}{*}{ 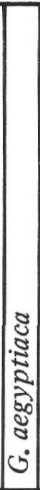 } & \multirow{2}{*}{$\begin{array}{l}0 \\
0 \\
0 \\
0 \\
0 \\
0\end{array}$} & \multirow{2}{*}{ 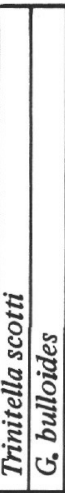 } & \multirow{2}{*}{ 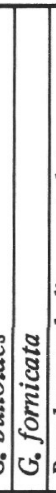 } & \multirow{2}{*}{ 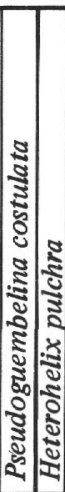 } & \multirow{2}{*}{ : } & \multirow{2}{*}{ 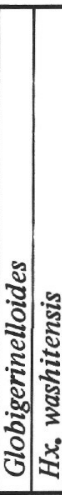 } & \multirow{2}{*}{ 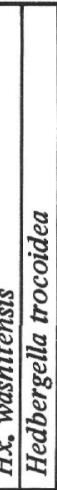 } & \multirow{2}{*}{\multicolumn{2}{|c|}{ 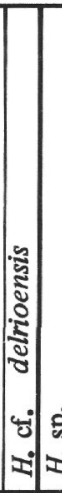 }} \\
\hline Age & Zone & $\begin{array}{l}\text { Core, Section, } \\
\text { Interval } \\
\text { (cm) }\end{array}$ & $\begin{array}{l}\text { Abun } \\
\text { dance }\end{array}$ & Preservation & & & & & & & & & & & & & \\
\hline \multirow{4}{*}{ 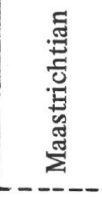 } & & $1, \mathrm{CC}$ & B & & & & & & & & & & & & & & \\
\hline & & $2, \mathrm{CC}$ & $\mathrm{B}$ & & & & & & & & & & & & & & \\
\hline & & $3, \mathrm{CC}$ & $\mathrm{R}$ & $\mathrm{M}$ & $\bullet$ & - & $\cdot$ & $\bullet$ & $\bullet \cdot$ & $\cdot$ & & & & & & & \\
\hline & & $4, \mathrm{CC}$ & & & & & & & & & & & & & & & \\
\hline \multirow{6}{*}{. } & & $5, \mathrm{CC}$ & $\mathrm{R}$ & $\mathbf{P}$ & & & & & - & $\bullet$ & $\cdot$ & $\bullet \bullet$ & & & & & \\
\hline & & $6, \mathrm{CC}$ & $\mathrm{R}$ & $\mathrm{P}$ & & & & & - & $\bullet$ & . & - & $\bullet$ & - & & & \\
\hline & & $7, \mathrm{CC}$ & & & & & & & & & - & - & $\bullet$ & - & & & \\
\hline & & $8, \mathrm{CC}$ & B & & & & & & & & & & $\bullet$ & - & & & \\
\hline & & $9, \mathrm{CC}$ & B & & & & & & & & & & & & & & \\
\hline & & $12, \mathrm{CC}$ & B & & & & & & & & & & & & & & \\
\hline \multirow{3}{*}{ 츨 } & & $13, \mathrm{CC}$ & $\mathrm{R}$ & $\mathrm{M}$ & & & & & & & & & & $\cdot \bullet$ & $\bullet$ & & \\
\hline & & $14, \mathrm{CC}$ & $\mathrm{F}$ & $\underline{P}$ & & & & & & & & & $\bullet$ & - & + & & $\bullet$ \\
\hline & & $15, \mathrm{CC}$ & $\mathbf{R}$ & $\mathbf{P}$ & & & & & & & & & & - $\bullet$ & $\bullet$ & $\bullet$ & $\bullet$ \\
\hline
\end{tabular}


TABLE 10

Range Chart of Neogene Planktonic Species at Site 171

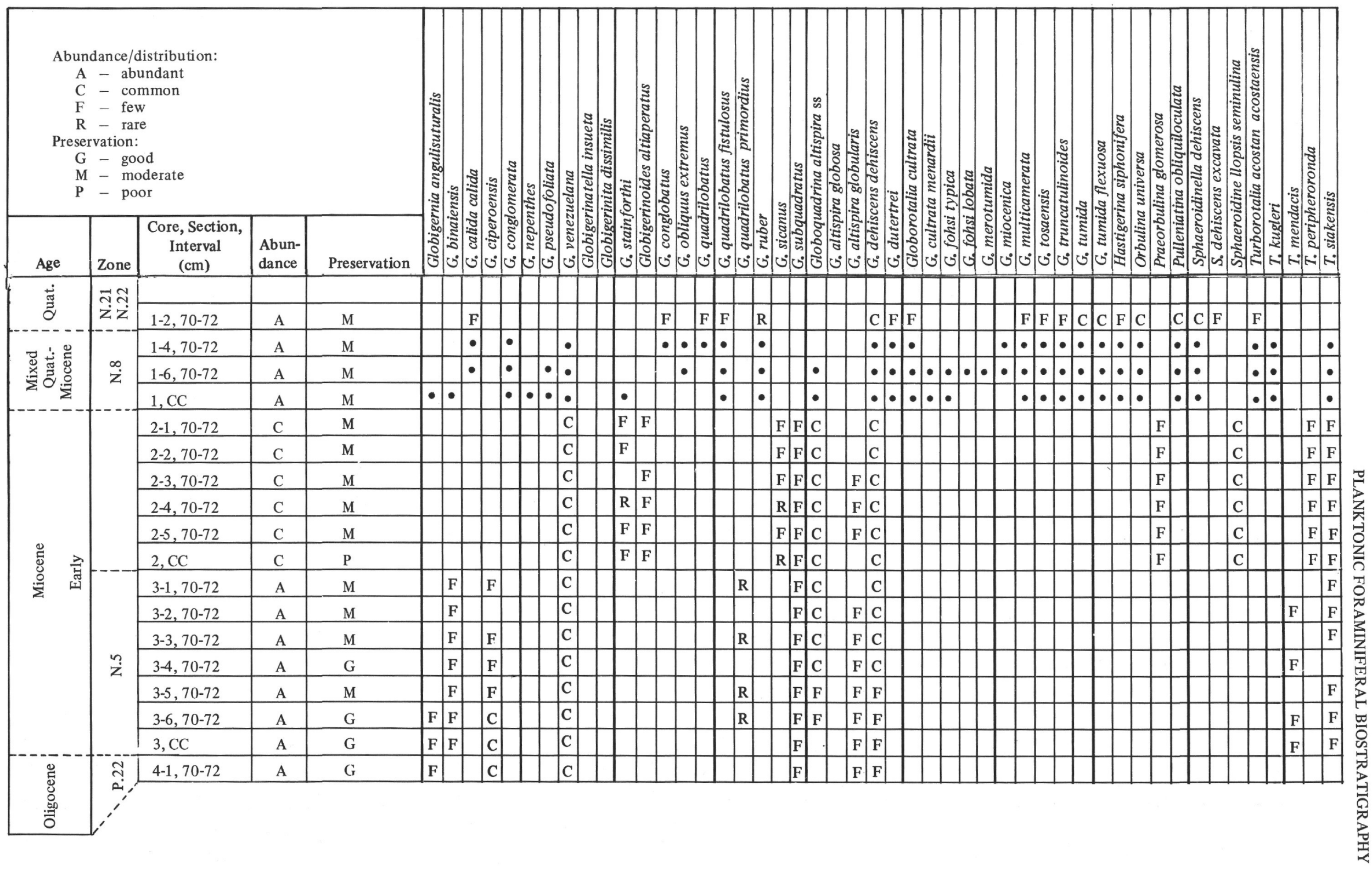


TABLE 11

Range Chart of Oligocene and Eocene Species at Site 171

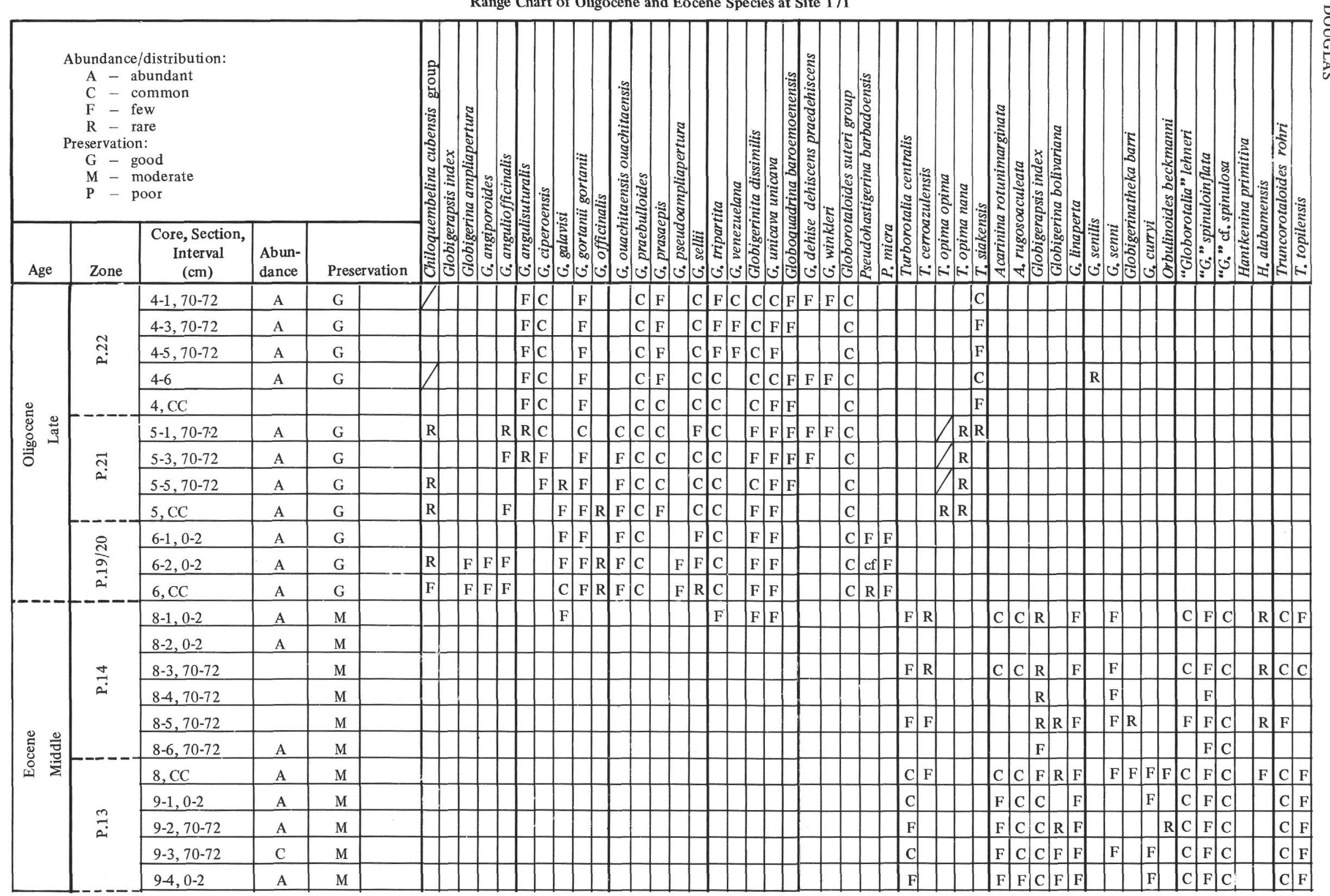


TABLE 12

Range Chart of Cretaceous Species at Site 171

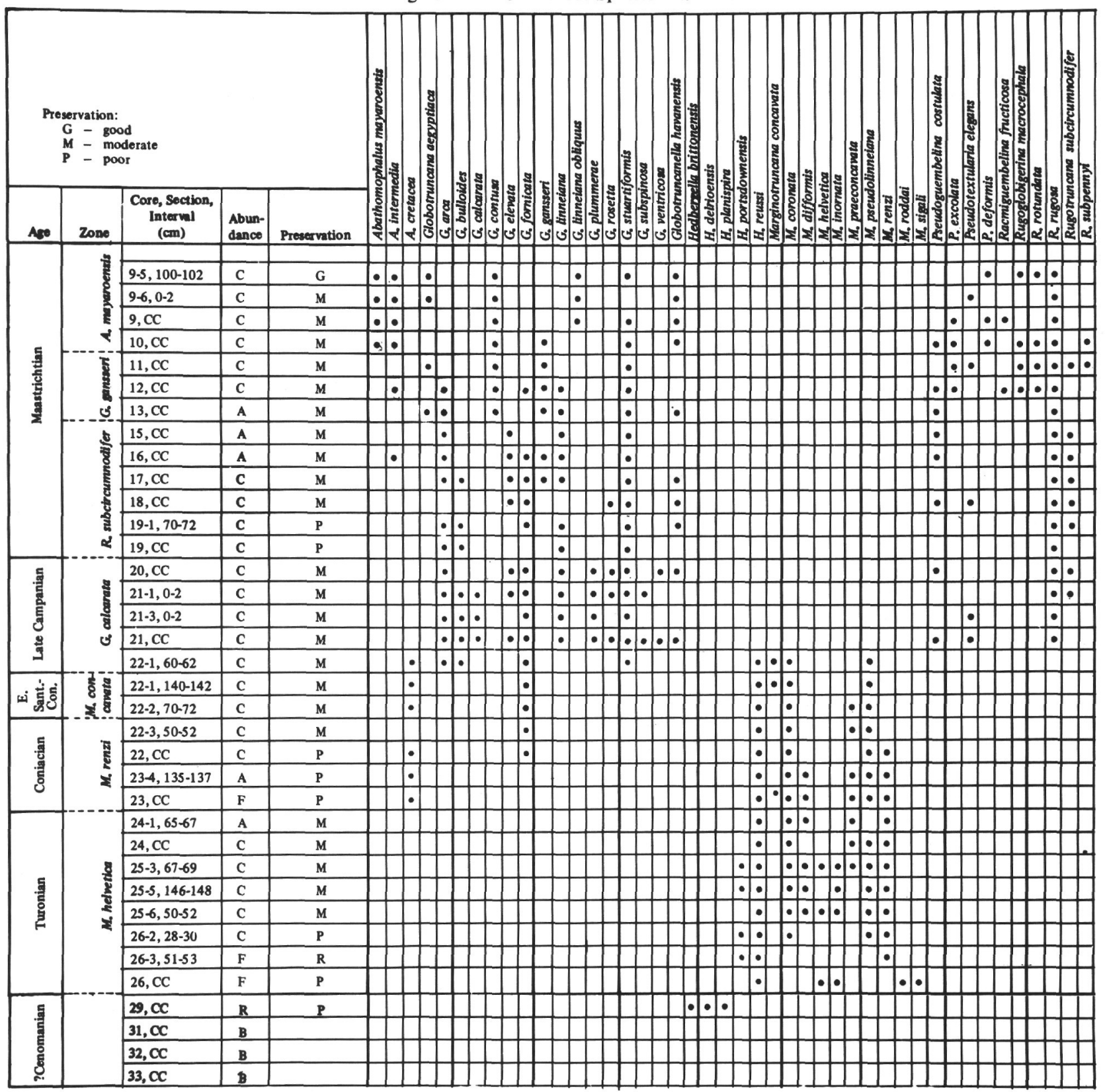

Except for a short interval between 180 and 208 meters, the section was continuously cored down to 357 meters and includes most of the upper Cretaceous. The bottom of the Abathomphalus mayaroensis Zone occurs in Sections 5 and 6 , Core 9, and admixed with the next older zone in the core catcher. The middle and lower Mastrichtian (Globotruncana gansseri and Rugotruncana subcircumnodifer Zones) occur in Cores 10 to 19 and the upper Campanian
(G. calcarata Zone) in Cores 19 to 21 ; the zonal biostratigraphy of this interval is complete, although recovery was poor in the Campanian. A change from nannofossil chalk ooze in Core 21 to glauconite-rich chalk in Core 22 apparently corresponds to a hiatus involving the lower Campanian and most or perhaps all of the Santonian. Lower Santonian or Coniacian planktonic foraminifera occur in Cores 22 and 23 . They are recrystallized and the 
assemblage is almost entirely composed of four or five globotruncanids and one or two species of Heterohelix. The foraminifera in Cores 24, 25, and 26, which span the Coniacian and Turonian, are also poorly preserved and difficult to zone. No foraminifera were found in Cores 27 or 28, and a few Hedbergella of probable Cenomanian age, in Core 29, are the last foraminifera found in the section.

Ostracods, similar to the species in Core 29, were recovered from Core 31.

\section{ACKNOWLEDGMENTS}

Financial support for this study was supplied in part by NSF grant GA 31622 and the Marathon Oil Company. The author wishes to thank Mrs. Eva Topfl and Mr. Scott Siddall for aid in sample preparation, statistical counts, and geochemical analyses.

\section{REFERENCES}

Beckmann, J. P., 1971. The foraminifera of sites 68 to 75: Initial Reports of the Deep Sea Drilling Project, Volume VIII. Washington (U. S. Government Printing Office), p. 713.

Berger, W., 1968. Planktonic foraminifera: selective solution and paleoclimatic interpretation: Deep-Sea Res., V. 15 , p. 34.

— 1969. Ecologic patterns of living planktonic foraminifera. Deep-Sea Res., V. 16, p. 1. 1970. Planktonic foraminifera: selective solution and the lysocline: Marine Geol., V. III, p. 8. 1971a. Sedimentation of planktonic foraminifera: Mar. Geol., V. II, p. 325.

1971b. Sedimentation of planktonic foraminifera: Mar. Geol., V. II, p. 325-358.

Berger, W. and von Rad, V., 1972. Cretaceous and Cenozoic sediments from the Atlantic Ocean: Initial Reports of the Deep Sea Drilling Project, Volume XIV. Washington (U.S. Government Printing Office), p. 787.

Blow, W. 1969. Late Middle Eocene to Recent Planktonic foraminiferal biostratigraphy: Intern at Conf. Plankt. Microfossils, 1st, Proc., V. 1, p. 199.

1970. Validity of biostratigraphic correlations based on the Globigerenacea: Micropaleontology, V. 1, p. 61 .

Bolli, H., 1967a. Planktonic foraminifera from the Oligocene-Miocene Cipero and Lengua Formations of Trinidad, B.W.I.: U.S. Nat. Mus. Bull., V. 215, p. 97. 1957b. Planktonic foraminifera from the Eocene Navet and San Fernando Formations of Trinidad, B.W.I.: U.S. Nat. Mus. Bull., V. 215, p. 155.

Bolli, H., 1957c. The genera Globigerina and Globorotalia in the Paleocene-Lower Eocene Lizard Springs Formation of Trinidad, B.W.I.: U.S. Nat. Mus. Bull., V. 215, p. 61 .

1966. The planktonic foraminifera in well Bodjonegoro-1 of Java: Ecolog. Geol. Helv. V. 59, p. 449.

Brönnimann, P. and Resig, J., 1971. A Neogene globigerinacean biochronologic time-scale of the southwest Pacific: Initial Reports of the Deep Sea Drilling Project, Volume VII, Washington (U.S. Government Printing Office), p. 1251.

Cordey, W.G., Berggren, W.A., and Olsson, R.K., 1970. Phlylogenetic trends in the planktonic foraminiferal genus Pseduohastigerina Banner and Blow, 1969: Micropaleontology, V.2, p. 235.

Douglas, R.G., 1971. Cretaceous foraminifera from the northwestern Pacific Ocean: Leg 6, Deep Sea Drilling Project: Initial Reports of the Deep Sea Drilling Project, Volume VI. Washington (U.S. Government Printing Office), p. 1027.

Grimsdale, T.F. and van Morkhoven, F.P.C.M., 1955. The ratio between pelagic and benthonic foraminifera as a means of estimating depth of deposition of sedimentary rocks: World Petrol. Congr., 4th, Proc. Sect. I/D, V. 4, p. 473.

Jenkins, D.G. and Orr, W., 1972. Planktonic foraminiferal biostratigraphy of the eastern Equatorial Pacific, DSDP Leg 9: Initial Reports of the Deep Sea Drilling Project, Volume IX. Washington (U.S. Government Printing Office), p. 1060.

Parker, F.L., 1954. Distribution of the foraminifera in the northeastern Gulf of Mexico: Mus. Comp. Zool. Bull., V. III, p. 454.

Parker, F. and Berger, W., 1971. Gaunal and solution patterns of planktonic foraminifera in surface sediments of the South Pacific: Deep-Sea Res., V. 18, p. 73.

Pessagno, E.A., 1967. Upper Cretaceous planktonic foraminifera from the Western Gulf Coastal Plain: Paleontogr. Am., V. 5, p. 245.

Savin, S. and Douglas, R. Stable isotope and magnesium geochemistry of Recent planktonic foraminifera from the South Pacific: Geol. Soc. Am. Bull. (in press).

Schott, W., 1935. Die Foraminiferen in dem acuatorialen Teil des Atalntischen Ozean: Deut. Atl. Exped. Meteor 1925-27, V. 3, p. 43.

Thiede, Jorn, 1972. Planktonische Foraminiferen in sedimenten vom ibero-marokkanischen Kontinetalrand: "Meteor" Forsch. Ergebnisse, Reihe C, V. 7, p. 15. 